\title{
Effects of protected area establishment and cash crop price dynamics on land use transitions 1990-2017 in north- eastern Madagascar
}

Jorge C. Llopis $^{\text {a,b* }}{ }^{*}$ Paul C. Harimalala ${ }^{\text {, }}$, Roger Bär ${ }^{\mathrm{a}, \mathrm{b}}$, Andreas Heinimann ${ }^{\mathrm{a}, \mathrm{b}}$, Zo H. Rabemananjara ${ }^{\mathrm{c}}$, and Julie G. Zaehringer ${ }^{\mathrm{a}}$.

${ }^{a}$ Centre for Development and Environment, University of Bern, Bern, Switzerland

${ }^{b}$ Institute of Geography, University of Bern, Bern, Switzerland.

${ }^{c}$ Ecole Supérieure des Sciences Agronomiques, Département des Eaux et Forêts, Université d'Antananarivo, Madagascar.

*corresponding author: Jorge C. Llopis, Centre for Development and Environment, Mittelstr. 34, 3012 Bern, Switzerland. E-mail: jorge.llopis@cde.unibe.ch

\begin{abstract}
We applied a participatory mapping approach supported by very high-resolution satellite imagery to reconstruct spatially explicit, year-to-year land use transitions in two highly biodiverse, data-scarce forest frontier landscapes in north-eastern Madagascar. We explored these transitions in the light of major continuous trends and discrete events highlighted by local farmers as influencing their land use decisions. Our results suggest that the process of establishing protected areas first reinforced ongoing deforestation, but later led to a significant reduction of forest loss rates. Recent cash crop booms appear to have induced agricultural intensification processes in our study landscapes, while also putting additional pressure on forests, as people may be encouraged to clear forest for cash crop cultivation. These findings are crucial to understanding rapid land use change processes in forest frontier contexts in the humid tropics, and especially to informing natural resource governance and development initiatives in complex mosaic landscapes.
\end{abstract}




\section{Keywords}

Sustainable agricultural intensification; participatory mapping; shifting cultivation; deforestation; protected areas; land use change.

\section{Introduction}

Land use change processes in the tropics pose challenges for sustainability at multiple scales (Foley et al., 2005; Verburg et al., 2015). Conversion of forest into agricultural and other land uses is one such process that is of high significance within broader processes of global change, as it contributes to increased carbon emissions (Brovkin et al., 2013; Houghton et al., 2012) and climate alteration (Snyder, Delire, \& Foley, 2004) at global and regional scales, as well as modification of hydrological cycles at the local scale (Sterling, Ducharne, \& Polcher, 2012). The past 30 years have seen an acceleration in many of these interconnected processes (Steffen, Broadgate, Deutsch, Gaffney, \& Ludwig, 2015) as well as in forest loss in the humid tropics (Kim, Sexton, \& Townshend, 2015), raising particular concern, as these regions harbour many of the world's biodiversity hotspots (Brooks et al., 2006; Mittermeier, Turner, Larsen, Brooks, \& Gascon, 2011; Sloan, Jenkins, Joppa, Gaveau, \& Laurance, 2014). Given that much of the agricultural expansion anticipated over the next decades is expected to take place in these regions (Laurance, Sayer, \& Cassman, 2014), pressures on tropical forests are likely to rise, spurred by global population growth and further compounded by climate change (DeFries, Rudel, Uriarte, \& Hansen, 2010; Fischer et al., 2011; Jantz et al., 2015; Tilman, Balzer, Hill, \& Befort, 2011).

Against this background, sustainable agricultural intensification is the main approach currently being debated to achieve the increase in agricultural output necessary to meet the global food needs of an increasing population with changing consumption habits, while preserving biodiversity and promoting ecosystem functioning (FAO, 2018; Rockström et al., 2017). However, sustainably governing socio-ecological systems through agricultural intensification is becoming ever more challenging, due to increasing competition between conservation, development, and subsistence objectives for increasingly scarce land-based natural resources (Lambin \& Meyfroidt, 2011; Niewöhner et al., 2016). These multiple demands are giving rise to what the land use science community has labelled telecoupled situations (Eakin et al., 2014; Liu et al., 2013), where distant drivers come to outpace local determinants of land use change processes. 
A key spatial planning approach to supporting sustainable agricultural initiatives in forest frontiers is the establishment of protected areas (PAs), the total surface of which has expanded in recent years (Watson, Dudley, Segan, \& Hockings, 2014), but whose very implementation might itself constitute a telecoupling process (Boillat et al., 2018). However, despite the continued increase in terrestrial surface under protection schemes, success in halting deforestation trends within (Janssen et al., 2018; Spracklen, Kalamandeen, Galbraith, Gloor, \& Spracklen, 2015), and around PAs (Lui \& Coomes, 2016) in the tropics remains elusive, with potentially severe implications for local populations (Adams et al., 2004; Ferraro \& Hanauer, 2014).

Despite decades of continued efforts to understand these and other dynamics of land use and land cover (LULC) change in the tropics (Bawa \& Dayanandan, 1997; Curtis, Slay, Harris, Tyukavina, \& Hansen, 2018; Lambin, Geist, \& Lepers, 2003; Meyfroidt, Lambin, Erb, \& Hertel, 2013), considerable uncertainties remain, particularly as to how external factors influence local landscape outcomes. Key knowledge gaps include a detailed understanding of the underlying mechanisms of cash crop expansion pathways (Meyfroidt et al., 2014), of the factors promoting shifts between land use regimes (Müller et al., 2014; Ramankutty \& Coomes, 2016), and of the concrete effect of PA establishment on ongoing LULC processes (Oestreicher et al., 2009). These uncertainties critically hamper ongoing theory-building efforts (Meyfroidt et al., 2018), particularly in regard to land use (DeFries, Foley, \& Asner, 2004; Foley et al., 2005) and forest transitions (Kull, 2017; Meyfroidt \& Lambin, 2011). Furthermore, although sociopolitical processes (e.g. political transitions and instability) and the occurrence of extreme weather events (e.g. cyclones) have been suggested to play a significant role in forest dynamics (Kuusela \& Amacher, 2016; Lim, Prescott, Alban, Ziegler, \& Webb, 2017), they remain understudied in LULC change analysis.

Remote sensing approaches are among the main tools used by the scientific community and conservation and development practitioners to monitor LULC dynamics in a timely way, but applying remote sensing in the case of complex mosaic landscapes in the humid tropics is hampered by a number of factors (Zaehringer, Llopis, Latthachack, Thein and Heinimann, 2018; see also SI 1). Participatory mapping approaches are increasingly employed to gather stakeholder-relevant spatial information not available through remote sensing technologies (Brown \& Kyttä, 2018; Heinimann, Flint, Bernhard, \& Hett, 2017; Nackoney, Rybock, Dupain, \& Facheux, 2013). However, their potential to complement remote sensing data to monitor land use change dynamics in forest frontier contexts remains largely untapped. 


\subsection{Sustainable agricultural intensification in Madagascar amid global change}

The case of Madagascar illustrates many of the above challenges faced by sustainable agricultural intensification in forest frontier contexts in the tropics. First, the Indian Ocean island is considered one of the 'hottest' biodiversity hotspots of the planet (Myers, Mittermeier, Mittermeier, Fonseca, \& Kent, 2000), which has led the country to be a prominent example of decades-long global efforts in biodiversity conservation (Gardner et al., 2018; Kull, 1996, 2014). Second, most of the global approaches to nature conservation supported by development can be found in Madagascar's different waves of PA expansion (Waeber, Wilmé, Mercier, Camara, \& Lowry II, 2016). These approaches range from Integrated Conservation and Development Projects (ICDPs) in the 1990s (Hufty \& Muttenzer, 2002; Marcus, 2001) and Community-Based Natural Resource Management (CBNRM) initiatives in the 2000s (Bertrand, Rabesahala-Horning, \& Montagne, 2009; Pollini, Hockley, Muttenzer, \& Ramamonjisoa, 2014) to REDD+ projects currently being tested in several of the country's PAs (Brimont, Ezzine-de-Blas, \& Karsenty, 2017; Neudert et al., 2018; Poudyal et al., 2016). Third, and in spite of these initiatives, expansion of subsistence shifting cultivation into forest is still the primary threat to biodiversity throughout much of Madagascar (Waeber et al., 2015; Zaehringer, Eckert, \& Messerli, 2015). While this trend parallels the continued importance of these agricultural systems in much of Sub-Saharan Africa (Heinimann et al., 2017), it contrasts with a general 'demise' of these practices witnessed in other world regions (Mertz et al., 2009; van Vliet et al., 2012). Nonetheless, environmental dynamics in other regions of the island, for example the central highlands, have led authors to point out that an incipient forest transition is taking place in some areas (McConnell, Viña, Kull, \& Batko, 2015). And fourth, rural populations and the Malagasy state obtain much of their revenue from the cultivation and sale of cash crops in both global and national markets. In many cases, these crops coexist with subsistence agriculture in forest frontier contexts. The problematic of cash crop booms in the context of shifting cultivation leading to agricultural expansion into forests in Madagascar has been described in several regions (Minten, Meral, Randrianarison, \& Swinnen, 2006; Scales, 2011). The persistence of these dynamics on the island has fed the debate on sustainable agricultural intensification in the country over the past decades. Scholars have approached the issue either from an applied perspective, by searching for ways of intensifying shifting cultivation systems or of replacing them altogether (Messerli, 2006), or from a more theoretical standpoint, by exploring local cases through classic-induced agricultural intensification theory (Laney, 2002; Pollini, 2012). 


\subsection{Goal of this study}

The overall goal of this study is to better understand the influence of external factors, i.e. PA establishment and cash crop price dynamics, on land use transitions in forest frontier landscapes in Madagascar. We define land use transitions as the change from one land use system to another, and we further disaggregate such transitions into land use trajectories, understood as year-to-year sequences of changes from one land use to another. Additionally, we explore the effect of key discrete events highlighted by local populations on these trajectories: cyclones and political crises.

In this work, we draw on the land use transition theory postulating that land use dynamics in a given region follow a series of stages, paralleling economic development and demographic growth (Grünbühel, Singh, \& Fischer-Kowalski, 2007; Jepsen et al., 2015; Mustard, Defries, Fisher, \& Moran, 2004). A first stage would see wildlands dominating the landscape, with hunting and foraging as main economic activities. This would be followed by frontier clearings for subsistence agriculture, giving way to a stage with increasing degrees of agricultural intensification and commercialization. In a final stage, industrial agriculture would dominate the landscape along with urban centres, with subsistence agriculture and wildlands confined to a small portion of the landscape, much of the latter under protection management regimes. (For a graphical depiction of these transitions, see DeFries et al., 2004.) Complementing this theory, forest transition theory has been proposed to explain a stage where land abandonment or implementation of protection regimes, among other potential factors, lead to a shift between a situation with net forest cover losses to one with net forest cover gains (Kull, Ibrahim, \& Meredith, 2007; Meyfroidt et al., 2018). In our study, we assess the possibility of such transitions in our study landscapes.

However, we acknowledge the somewhat abstract character of such stages, and the shortcomings of applying these to the case of Madagascar - whether a hunter-gatherer stage actually ever existed in Madagascar is still the subject of much debate (Hodgson, 2016). Nonetheless, a major reason for resorting to land use theory is that it allows us to structure the analysis and to focus on exploring potential factors that promote or hinder regime shifts between the different stages (Müller et al., 2014), which might in turn help to explain the prevalence of subsistence shifting cultivation systems amidst agricultural intensification trends.

To explore these land use transitions and trajectories, we selected two highly biodiverse forest frontier landscapes in the north-east of the country which have been undergoing 
processes of both agricultural expansion and intensification in recent decades. These two landscapes are particularly well suited to the overall goal of this study: They are located in the periphery of two recently established large PAs and are experiencing price booms for the two main export cash crops cultivated here, clove and vanilla. Three main objectives served to reach our overall goal. The first was to capture the continuous, spatially explicit land use trajectories at plot level, which at the aggregate level will serve to reconstruct the land use transitions in our two study landscapes over the past 28 years. Second, based on the results of the previous step, we aimed to explore the potential role that continuous trends highlighted by local farmers as relevant in land use decision making processes might have played in shaping land use trajectories of agricultural expansion and intensification. Although not exclusively, we situate agricultural expansion in the context of the establishment of PAs and the different natural resource governance regimes for their buffer zones. Likewise, we mostly, but not only, explored agricultural intensification in regard to the evolution of clove and vanilla prices. In this study, we understand agricultural intensification as an increase in the real value of output per unit of land (Byerlee, Stevenson, \& Villoria, 2014; Laney, 2002) assessed at the aggregate landscape level. We evaluated two main pathways based on land use dynamics (Rasmussen et al., 2018; Zaehringer, Hett, Ramamonjisoa, \& Messerli, 2016): substitution of shifting cultivation systems by permanent cultivation systems, either for commercial purposes (open and closed agroforest land uses for vanilla production, and clove-related land uses for clove production) or for subsistence production (irrigated rice fields), on the one hand; and the introduction of clove cultivation into agroforestry systems or onto pasture land, on the other, though more briefly. Third, we looked at two key discrete events (cyclones and political crises) to explore their potential contribution to the land use trajectories in our study landscapes.

\section{Case study areas}

The two forest frontier study landscapes, Beanana and Fizono, are located in northeastern Madagascar (Figure 1, Table 1), a region hosting the country's largest tracts of humid evergreen forest and two of the largest PAs on the island. Situated on the periphery of Makira Natural Park and Masoala National Park, respectively, the two landscapes have socialecological similarities and differences. The main local livelihood activities in both sites are subsistence rice cultivation, either in irrigated paddies at the valley bottoms or on rain-fed shifting cultivation plots on hill slopes; cash crop production on agroforestry plots, mainly vanilla (Vanilla planifolia) and clove (Syzygium aromaticum), on occasion combined with subsistence fruit crops; and zebu herding. Since shifting cultivation is considered the main 
cause of deforestation in the area, the recently established PAs in the region ban the expansion of shifting cultivation fields into forest land in core areas as well as in the buffer zone. With regard to cash crop production, vanilla and clove have both undergone strong price fluctuations in recent years and are currently experiencing price booms (Brownell, 2011; Danthu et al., 2014; Zhu, 2018). In parallel, the forests of Makira and Masoala have been centre stage in the illegal extraction of rosewood (Dalbergia spp.), which intensified substantially during Madagascar's 2009 political crisis and the following transition period (Randriamalala \& Liu, 2010; Schuurman \& Lowry, 2009; Waeber, Schuurman, \& Wilmé, 2018); it is worth noting here that trade in rosewood has been related to the recent spike in vanilla prices (Anonymous, 2018). Additionally, and as in much of Madagascar, tropical cyclones regularly make landfall in this region, with important implications for local livelihoods and forest dynamics (Brimont, Ezzine-de-Blas, Karsenty, \& Toulon, 2015; Brown, 2009). The main differences between the two landscapes are that Beanana is more remote than Fizono, with a lower population density, greater reliance of the local population on shifting cultivation, and more recent establishment of the PA (Table 1).

Table 1. Characteristics of study landscapes.

\begin{tabular}{ccccccccccc}
\hline Village & Creation & $\begin{array}{c}\text { Inhabitants } \\
\text { (2015) }\end{array}$ & $\begin{array}{c}\text { Pop. } \\
\text { Density in } \\
\text { inhab./km² }\end{array}$ & $\begin{array}{c}\text { Study } \\
\text { landscape } \\
\text { area }\end{array}$ & $\begin{array}{c}\text { Area within } \\
\text { core zone }\end{array}$ & $\begin{array}{c}\text { Area within } \\
\text { buffer zone }\end{array}$ & $\begin{array}{c}\text { Area within } \\
\text { sustainable use } \\
\text { zone }\end{array}$ & $\begin{array}{c}\text { Area } \\
\text { outside PA }\end{array}$ & $\begin{array}{c}\text { Accessibility } \\
\text { (hours to } \\
\text { district capital) }\end{array}$ \\
\hline Fizono & $1790 \mathrm{~s}$ & 3,851 & 53.7 & $71.65 \mathrm{~km}^{2}$ & $27.8 \%$ & $3.5 \%$ & N/A & $68.7 \%$ & 7 hours \\
\hline Beanana & 1894 & 721 & 19.1 & $37.67 \mathrm{~km}^{2}$ & $7 \%$ & $92.2 \%$ & $0.8 \%$ & $0 \%$ & 11 hours \\
\hline
\end{tabular}

In relation to the PAs, Beanana's landscape falls entirely within one or another of the different natural resource management regimes related to Makira Natural Park (hereafter referred to as Makira PA), i.e. core, buffer, and sustainable use zones (Table 1). The Makira Forest Project was launched in 2001 (Meyers, 2001), although the forest did not gain temporary protection status until 2005, when it was established as a New Protected Area (NPA). Eventually, in 2012 Makira became an IUCN Category II Protected Area, managed by the international conservation organization Wildlife Conservation Society (WCS). Its core areas cover over 370,000 ha, with an additional buffer zone around the PA covering over 340,000 ha, whose management began to be transferred to local communities in 2006. This process involved the creation of base communities (COBAs, from the French Communautés de Base) to which management rights would be transferred. In the case of our study landscape in 
Beanana, management rights for the forests outside Makira PA's core area were transferred to local communities in 2014. Makira PA is a REDD+ project, with the first sale of carbon credits signed in December 2013 (WCS, 2018).

Figure 1. Location of the study landscapes. Sources: Forest cover: ONE et al. 2013; PA boundaries: MNP 2017 and WCS 2017; Digital elevation model: DLR 2017.
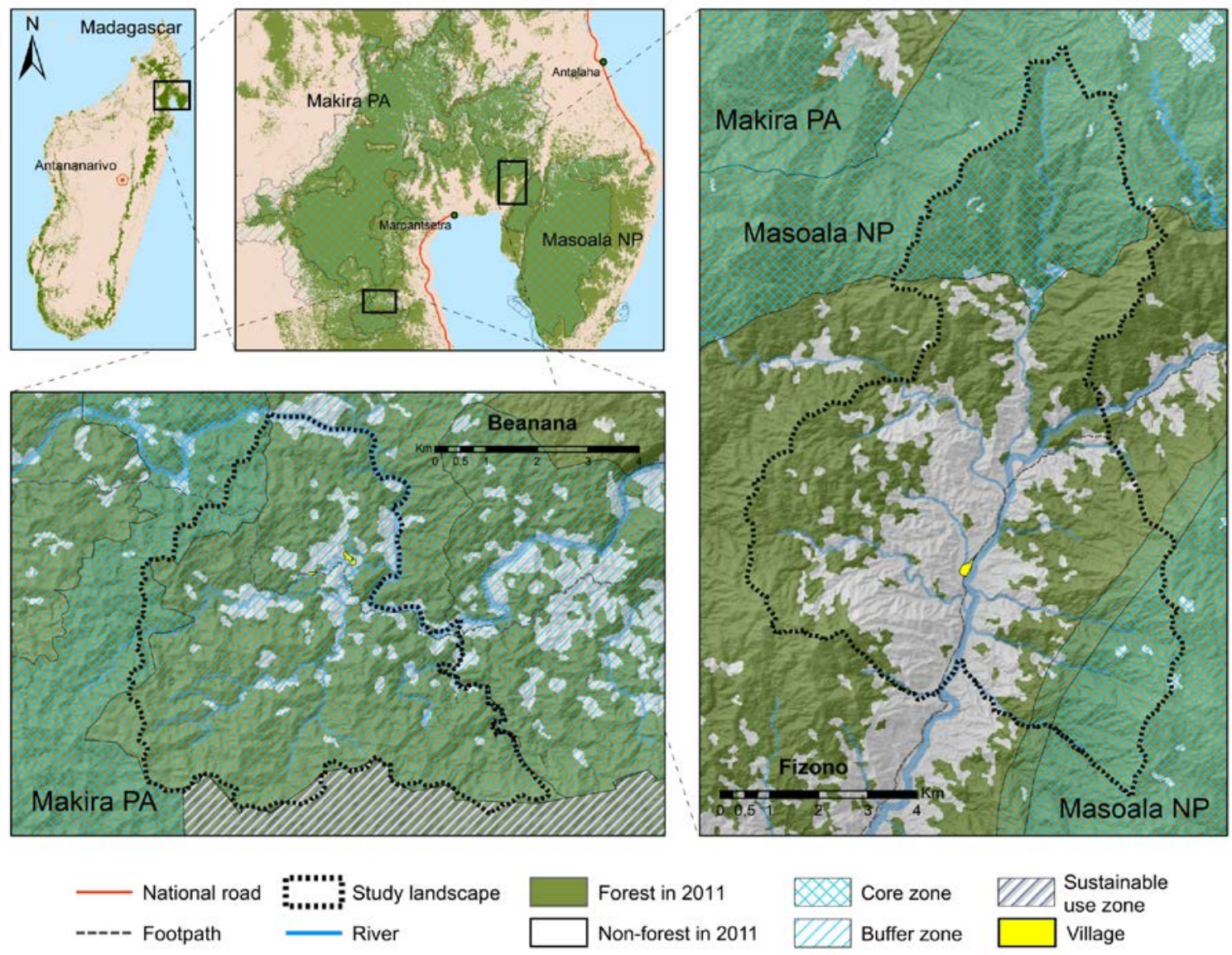

Most of our study landscape in Fizono is located at the periphery of Masoala National Park (hereafter Masoala NP), although nearly 28\% of the landscape falls within the park's core zone (Table 1). Intervention to create an ICDP in Masoala began in 1993 with substantial support from WCS (Keller, 2009), and lasted until 1997, when Masoala was declared a national park (Holmes, 2007; Kremen et al., 1999). Masoala NP is also an IUCN Category II Protected Area, in this case managed by an institution under the supervision of the Malagasy state, the Madagascar National Parks (MNP) organization. Masoala NP covers over 230,000 ha across four terrestrial and three marine areas, plus a buffer zone covering some 20,000 ha around certain sectors of the park (MNP, 2015, 2017). The management of the area of Fizono's 
landscape located within Masoala NP's buffer zone (Figure 1, Table 1) was transferred to local communities in 2011 through creation of the local COBA.

\section{Methods and materials}

For this study, we adapted the methodology developed by (Zaehringer et al., 2018) to reconstruct land use transitions in the humid tropics. The approach combines object-based spatial delineation of the plots in our study landscapes based on very high-resolution (VHR, $0.5 \mathrm{~m} /$ pixel) remote sensing imagery, with participatory methods supported by ancillary data (Table 2) to identify land use and land use trajectories in each plot from 1990 to 2017. In order to gain explanatory insights into the temporally explicit factors affecting local land use decision-making, and thus the land use transitions in the study landscapes, we gathered qualitative evidence through key informant interviews and participatory workshops.

Figure 2. Methodological mapping workflow employed in this study.

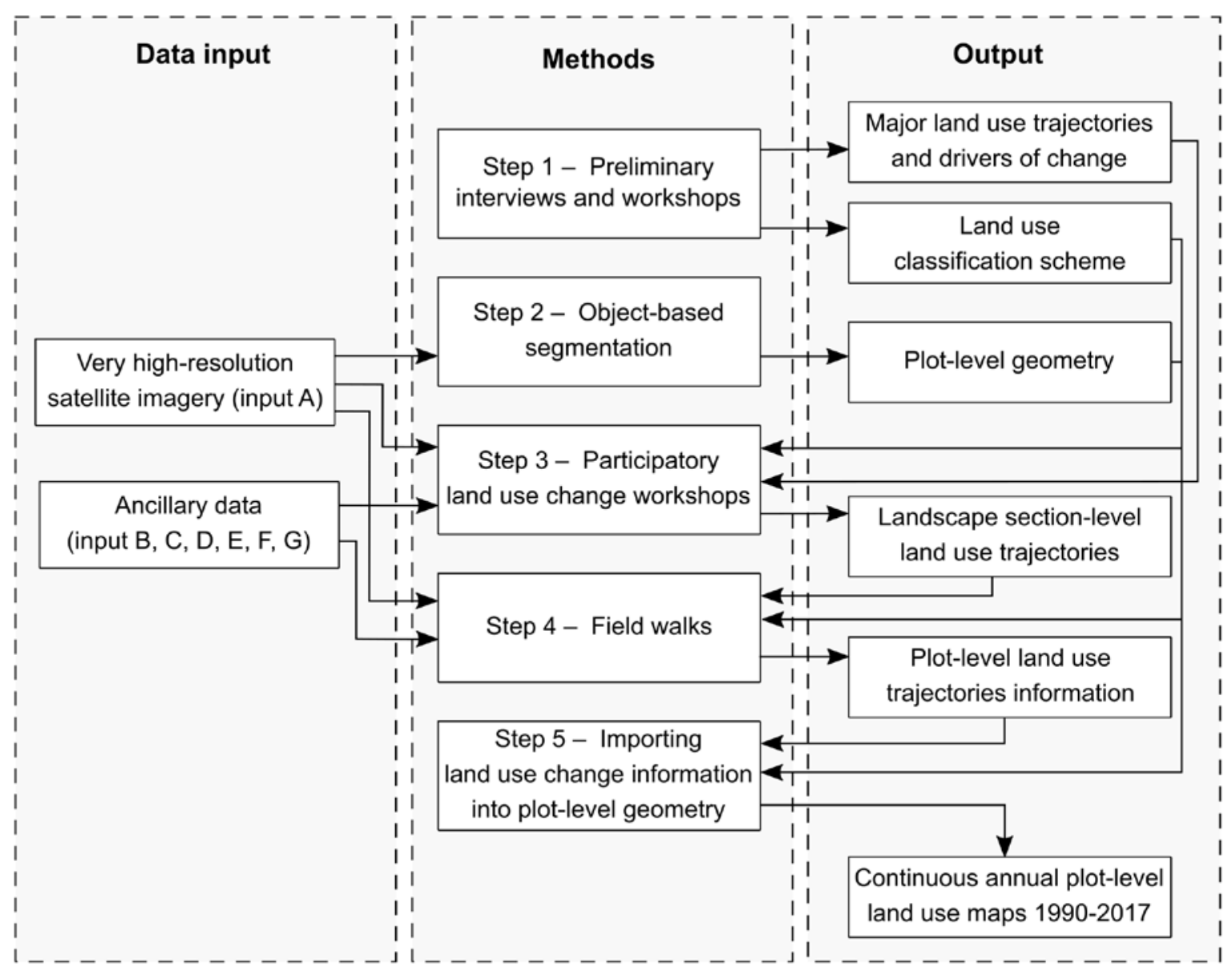


We conducted participatory fieldwork in April 2016, from October to December 2016, and from August to November 2017, with a short follow-up visit in February 2019 to check our findings with local participants. As the methodology has previously been published (Zaehringer et al., 2018), we only briefly describe the steps of the mapping workflow employed in the study (Figure 2) and provide a detailed description in the supplementary information (SI 1).

Table 2. Remote sensing and GIS data used. ${ }^{1:}$ Given the length of the list, we provide in SI 2 a complete list of the Sentinel and Landsat remote sensing data employed in this study.

\begin{tabular}{|c|c|c|c|c|c|}
\hline $\begin{array}{l}\text { Workflow } \\
\text { input }\end{array}$ & Sensor / Data & Date / Source & $\begin{array}{c}\text { Spatial } \\
\text { resolution }\end{array}$ & $\begin{array}{c}\text { Period of } \\
\text { time }\end{array}$ & Study landscape \\
\hline \multirow{3}{*}{ A } & Pléiades & 05 Feb, 2017 & $0.5 \mathrm{~m} /$ pixel & Current & Fizono \\
\hline & Pléiades & 29 Mar, 2016 & $0.5 \mathrm{~m} /$ pixel & Current & Beanana \\
\hline & Pléiades & 16 Mar, 2016 & $0.5 \mathrm{~m} /$ pixel & Current & Fizono \\
\hline \multirow{5}{*}{$\mathrm{B}$} & Pléiades & 09 Jul, 2014 & $0.5 \mathrm{~m} /$ pixel & Past & Fizono \\
\hline & World View 2 & 15 May, 2012 & $0.5 \mathrm{~m} /$ pixel & Past & Fizono and Beanana \\
\hline & World View 2 & 22 Jan, 2012 & $0.5 \mathrm{~m} /$ pixel & Past & Fizono \\
\hline & World View 2 & 23 Feb, 2011 & $0.5 \mathrm{~m} /$ pixel & Past & Fizono \\
\hline & Quick Bird 2 & 27 May, 2006 & $0.5 \mathrm{~m} /$ pixel & Past & Beanana \\
\hline \multirow[b]{2}{*}{$\mathrm{C}$} & Sentinel & 1 & 10 m/pixel & $2015-2018$ & Fizono and Beanana \\
\hline & $\begin{array}{c}\text { Landsat } 5 \text { TM, } 7 \text { ETM+ } \\
\text { and } 8 \text { OLI }\end{array}$ & 1 & 30 m/pixel & 1990-2018 & Fizono and Beanana \\
\hline$D$ & Regional land cover & Zaehringer et al. 2015 & 30 m/pixel & $\begin{array}{c}\text { 1995; } 2005 ; \\
2011\end{array}$ & Fizono and Beanana \\
\hline$E$ & $\begin{array}{l}\text { Madagascar forest cover } \\
\text { evolution data }\end{array}$ & $\begin{array}{l}\text { MEEF et al. } 2007 \\
\text { ONE et al. } 2013\end{array}$ & 30 m/pixel & $\begin{array}{l}1990 ; 2000 ; \\
2005 ; 2010\end{array}$ & Fizono and Beanana \\
\hline$F$ & Global Forest Change & Hansen et al. 2013 & 30 m/pixel & $2000-2017$ & Fizono and Beanana \\
\hline G & TanDEM-X data & DLR 2017 & 12 m/pixel & 2017 & Fizono and Beanana \\
\hline
\end{tabular}

In Step 1, we obtained general information about village settlement history, predominant land uses, overall trajectories of change, and complementary information about the landscape through interviews with local authorities and farmers. We also undertook preliminary field walks with local farmers to collect a first series of GPS points for all land uses in each study area, which subsequently helped to outline the land use classification scheme (Table 3). We then conducted preliminary workshops with farmers to elicit the major land use trajectories and drivers of land use change in the villages, the latter constituting the continuous trends and discrete events we explore in this study. The workshops also helped to further refine the classification scheme presented in Table 3, which was employed in the following mapping steps (see SI 1 for further details on the classification scheme). To gain insight into the history of the PAs and the evolution of the different natural resource management regimes in our study 
landscapes, we also conducted interviews with PA managers, forest ministry officials, and administrative authorities in the national capital Antananarivo and in the capital of the district where our study landscapes are located, Maroantsetra.

In Step 2, we elaborated the spatially explicit structure of the plots in our study landscapes, into which the participatory land use change information would be entered. To this end, we delineated in eCognition Developer software (Trimble, 2013) the geometry of the spatial units of classification of land use in our study landscapes, i.e. the agricultural plots, based on the most recent VHR multispectral satellite imagery available, acquired by the Pléiades satellite in 2016 and 2017 (Table 2). The output of this step was the plot-level geometry for both study landscapes, which constituted the structure in which to input the participatory land use change information collected in the next steps (SI 3). This geometry was further refined based on the spatially explicit information collected during the field walks, as explained below.

Step 3 had a threefold objective. First, to delineate the study landscape boundaries; second, to obtain the spatially explicit context knowledge needed to plan the field walks; and third, to elicit the trajectories of land use change for the different sections of the landscape. To this end, we conducted a participatory land use changemapping workshop in each study site (Beanana: full-day, eight participants; Fizono: halfday, five participants). For the workshops, we printed the most recent VHR satellite imagery and the ancillary remote sensing and Landsat-based GIS data we work with in this study (Table 2), to further support the discussions. The workshops gave us an understanding of the land use trajectories for all sections of the study landscapes, including the most recent plot-level land use change information for a substantial portion of the landscapes. During the workshops, we also defined the boundaries of the study landscapes, although we should note that these boundaries might not correspond with all the land worked by the population of a given village, nor is the land included within these landscapes necessarily worked exclusively by the people of a given village. This is due to the frequent existence of land tenure and usufruct agreements between communities and families in this region, whose contents we do not examine as this would have exceeded the scope of our study. We acknowledge that this limitation calls for caution when interpreting our results (see SI 1 for further details). 
Table 3. Land use classification scheme.

\begin{tabular}{|c|c|c|c|c|}
\hline $\begin{array}{l}\text { Land use } \\
\text { category }\end{array}$ & Land use class & Local name & $\begin{array}{l}\text { Main } \\
\text { crops }\end{array}$ & Land use description \\
\hline \multirow{3}{*}{ Forest } & Old-growth forest & Atiala velona & N/A & Mature unlogged forest \\
\hline & Secondary forest & $\begin{array}{l}\text { Boribatana; } \\
\text { savoka matoy }\end{array}$ & N/A & $\begin{array}{l}\text { Forest regrowth originating from a shifting cultivation fallow } \\
\text { field, not cultivated for at least five years. }\end{array}$ \\
\hline & Degraded forest & $\begin{array}{l}\text { Atiala tevy revo; } \\
\text { rokotro'ala; } \\
\text { pok'afo }\end{array}$ & N/A & $\begin{array}{l}\text { Old-growth forest under exploitation for timber extraction, } \\
\text { and/or burned as a result of fire escape from a nearby shifting } \\
\text { cultivation field. }\end{array}$ \\
\hline $\begin{array}{l}\text { Shifting } \\
\text { Cultivation }\end{array}$ & $\begin{array}{l}\text { Shifting } \\
\text { Cultivation }\end{array}$ & Jinja; savoka & Rice & $\begin{array}{l}\text { Field under shifting cultivation, most commonly for rice } \\
\text { production. This land use includes both fields cultivated and } \\
\text { fields left fallow for vegetation regrowth before the next cycle of } \\
\text { cultivation. }\end{array}$ \\
\hline \multirow{3}{*}{$\begin{array}{l}\text { Clove- } \\
\text { related uses }\end{array}$} & $\begin{array}{l}\text { Dense clove } \\
\text { plantation }\end{array}$ & Alan'jirofo & Clove & $\begin{array}{l}\text { Field exclusively dedicated to the cultivation of clove trees. } \\
\text { Clove density varies between } 175 \text { and } 250 \text { trees/ha. }\end{array}$ \\
\hline & $\begin{array}{l}\text { Young clove } \\
\text { plantation }\end{array}$ & $\begin{array}{l}\text { Alan'jirofo vao } \\
\text { vao; savoka } \\
\text { misy jirofo }\end{array}$ & Clove & $\begin{array}{l}\text { Field recently and for the first time prepared for clove } \\
\text { cultivation, with clove seedlings already planted. This land use } \\
\text { comprises the stage between seedling plantation and the clove } \\
\text { trees start giving production. This stage commonly lasts around } \\
\text { seven years, although it can span between five and fifteen years, } \\
\text { depending on soil conditions, location, slope, former land use, } \\
\text { and other factors. This land use is a transition towards either } \\
\text { dense clove plantation, pasture with clove, or clove-dominated } \\
\text { agroforest. }\end{array}$ \\
\hline & Pasture with clove & $\begin{array}{l}\text { Kijana } \\
\text { amin'jirofo }\end{array}$ & $\begin{array}{l}\text { Grass, } \\
\text { clove }\end{array}$ & $\begin{array}{l}\text { Pasture land planted with clove trees, dedicated to both zebu } \\
\text { grazing and clove production. Clove density varies between } 90 \\
\text { and } 100 \text { trees/ha. }\end{array}$ \\
\hline \multirow[b]{2}{*}{ Paddy rice } & Irrigated paddy & Horaka & Rice & Irrigated paddy rice field under cultivation. \\
\hline & Dry paddy & $\begin{array}{l}\text { Horaka tsy- } \\
\text { ampy rano; } \\
\text { savoka-horaka }\end{array}$ & N/A & $\begin{array}{l}\text { Formerly irrigated paddy rice fields, temporary or permanently } \\
\text { left fallow due to a lack of water for irrigation or soil fertility. It } \\
\text { might already be in the process of being transformed into other } \\
\text { land uses. }\end{array}$ \\
\hline \multirow{3}{*}{ Agroforest } & $\begin{array}{l}\text { Clove-dominated } \\
\text { agroforest }\end{array}$ & $\begin{array}{l}\text { Taninjirofo; } \\
\text { Tanimboly } \\
\text { amin'jirofo }\end{array}$ & $\begin{array}{l}\text { Clove, } \\
\text { vanilla }\end{array}$ & $\begin{array}{l}\text { Agroforest primarily dedicated to cultivating clove, although it } \\
\text { might also contain vanilla and subsistence fruit trees. Commonly } \\
\text { this land use is a former open agroforest plot, where clove trees } \\
\text { have been introduced. Clove density varies between } 90 \text { and } 110 \\
\text { trees/ha. }\end{array}$ \\
\hline & Closed agroforest & $\begin{array}{l}\text { Tanimboly } \\
\text { amin'kakazo-bé }\end{array}$ & $\begin{array}{l}\text { Vanilla, } \\
\text { clove }\end{array}$ & $\begin{array}{l}\text { Agroforest for cash crops and with trees not intended for } \\
\text { agricultural production. This land use follows two main } \\
\text { dynamics. First, and most commonly, it corresponds to a former } \\
\text { old-growth or degraded forest plot where most of the large trees } \\
\text { have been extracted, and recently and for the first time planted } \\
\text { with cash crops. Second, it can be a former open agroforest plot } \\
\text { where large trees not dedicated to agricultural production have } \\
\text { grown. }\end{array}$ \\
\hline & Open agroforest & Tanimboly & $\begin{array}{l}\text { Vanilla, } \\
\text { coffee, } \\
\text { mango, }\end{array}$ & $\begin{array}{l}\text { Agroforest with most of the crops planted for subsistence and/or } \\
\text { cash crop production. Vanilla and coffee are the cash crops most } \\
\text { commonly found in this land use. }\end{array}$ \\
\hline \multirow[b]{2}{*}{ Pasture } & $\begin{array}{l}\text { Pasture without } \\
\text { trees }\end{array}$ & Kijana & Grass & Pasture land exclusively dedicated to zebu grazing. \\
\hline & $\begin{array}{l}\text { Pasture with trees, } \\
\text { no clove }\end{array}$ & $\begin{array}{l}\text { Kijana } \\
\text { amin'manga, } \\
\text { litchi, kakazo, } \\
\text { etc. }\end{array}$ & $\begin{array}{l}\text { Grass, } \\
\text { mango, } \\
\text { litchi, } \\
\text { etc. }\end{array}$ & Pasture land with subsistence and other trees, but no clove trees. \\
\hline \multirow{6}{*}{ Various } & Bamboo & Alan'bolo & N/A & $\begin{array}{l}\text { Area with bamboo planted, commonly as a separation between } \\
\text { agricultural fields, or to signal ownership of a plot. }\end{array}$ \\
\hline & Bare soil & $\begin{array}{l}\text { Vato, lalana, } \\
\text { lavaka, }\end{array}$ & N/A & $\begin{array}{l}\text { Area covered with sand, stone, or other material where } \\
\text { cultivation is not possible. }\end{array}$ \\
\hline & Not cultivated & Tsy amboly & N/A & $\begin{array}{l}\text { Area not currently cultivated, but that could be readily } \\
\text { transformed into agricultural production. }\end{array}$ \\
\hline & Population centre & $\begin{array}{l}\text { Tanana; } \\
\text { campement }\end{array}$ & N/A & Built-up settlements, or scattered hamlets. \\
\hline & Water & Rano; driaka & N/A & Water body or water course. \\
\hline & Field separation & - & N/A & $\begin{array}{l}\text { Area separating agricultural fields, not currently cultivated, but } \\
\text { that could be readily transformed into agricultural production. } \\
\text { Commonly it is a wide separation between paddy fields, or a } \\
\text { living fence. }\end{array}$ \\
\hline
\end{tabular}


In Step 4, we collected in a participatory process continuous information on the trajectories of land use change at plot level for the plots on which we had not been able to compile information during the participatory workshops. To this end, we conducted 25 field walks in the two villages (Table 4), for which we required the assistance of one or two local farmers knowledgeable about the different sections of the landscape covered in each walk. During the walks, we asked participants to identify the current and previous land uses in each plot, and the date on which one land use changed to another, particularly in the last 30 years. We then registered the information with GPS points, geolocalized pictures, and a voice recorder.

Table 4. Field walks methodological details. ${ }^{1:}$ Old-growth forest and water bodies by 2017 are excluded from this estimate.

\begin{tabular}{cccccccc}
\hline $\begin{array}{c}\text { Study } \\
\text { landscape }\end{array}$ & Area mapped & $\begin{array}{c}\text { Number of } \\
\text { plots }^{1}\end{array}$ & $\begin{array}{c}\text { Number of } \\
\text { field walks }\end{array}$ & $\begin{array}{c}\text { Total km } \\
\text { field walks }\end{array}$ & $\begin{array}{c}\text { Accumulated } \\
\text { elevation }\end{array}$ & $\begin{array}{c}\text { Number of ground } \\
\text { truth points }\end{array}$ & $\begin{array}{c}\text { Number of geolocalised } \\
\text { pictures }\end{array}$ \\
\hline Beanana & $37.67 \mathrm{~km}^{2}$ & 3,430 & 11 & 78.4 & $3,993 \mathrm{~m}$ & 930 & 3,054 \\
\hline Fizono & $71.65 \mathrm{~km}^{2}$ & 10,457 & 14 & 112.9 & $6,637 \mathrm{~m}$ & 1,204 & 5,226 \\
\hline
\end{tabular}

Finally, the main goal of Step 5 was to enter the continuous participatory land use change information collected in the two previous steps into the plot-level geometry using GIS software. This step also served to refine the plot structure to account for the changes in plot shape over the years, and to define the definitive boundaries of our study landscapes (for further details see SI 1). The output of this step was a plot-level land use map for each of the 28 years covered in our study period in the two study landscapes (Figure 3).

In terms of the accuracy of the maps developed through this participatory approach, the level of detail we aimed at mapping, i.e. land use, precluded conducting a traditional remote sensing accuracy assessment (Congalton \& Green, 2009). Conducting such an assessment would have required VHR satellite imagery to evaluate land use through the entire study period (1990-2017), but this imagery only became available in the last decade. We believe that our reconstruction of the landscape dynamics in our study areas is sufficiently accurate, thanks to the triangulation of information obtained from local farmers in the mapping workshops, data gathered during the field walks, and virtually all ancillary data existing for these areas. Nonetheless, further details about the implications of our choice of participatory mapping approach can be found in (Zaehringer et al., 2018). 


\section{Results}

In this section, we present the land use trajectories and transitions in our two study landscapes from 1990 to 2017. An overview of the land use maps for 1990 and 2017 is presented in Figure 3, while an animated version of the continuous annual land use change maps for the entire period can be found here: Beanana and Fizono.

Figure 3. Land use maps for 1990 and 2017. A) Beanana. B) Fizono.

\section{0}
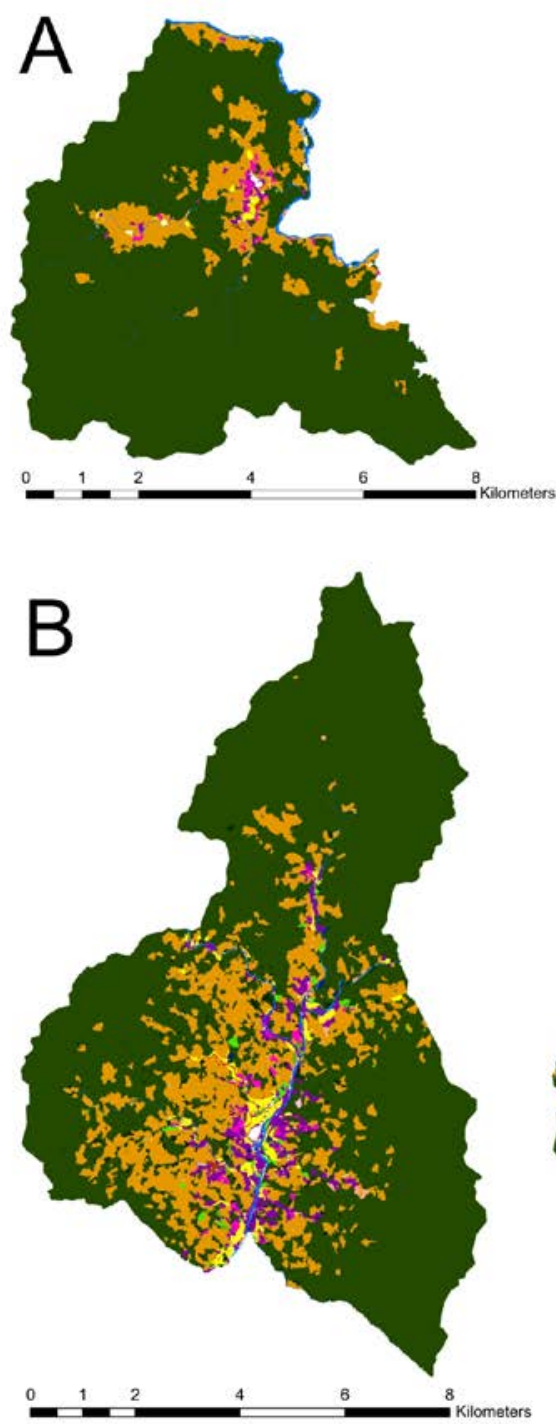

\section{7}
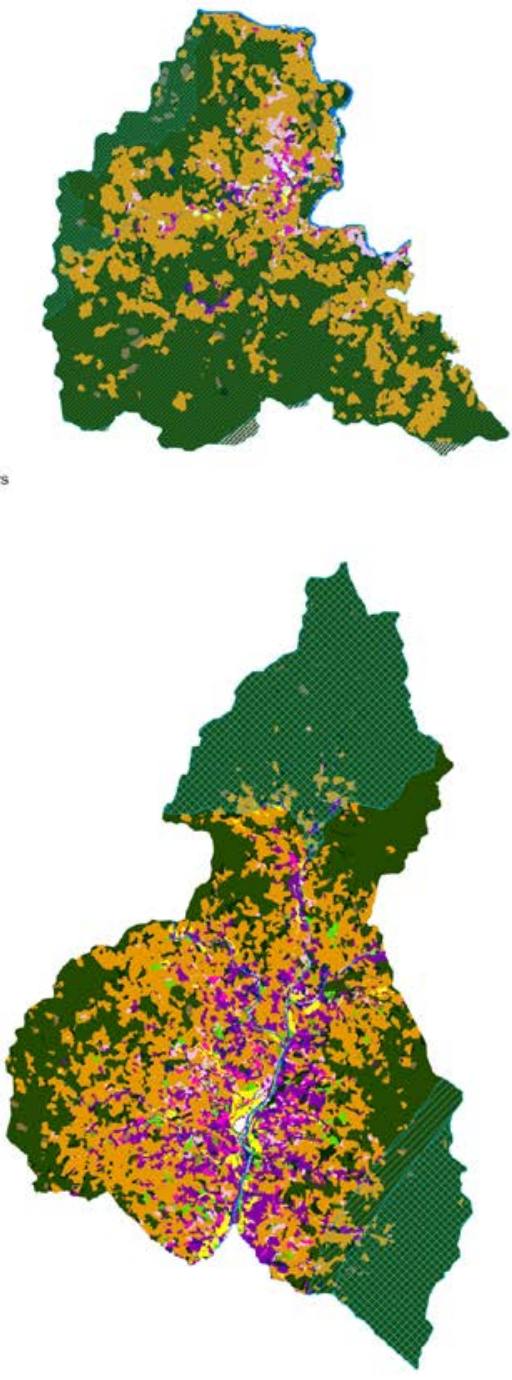
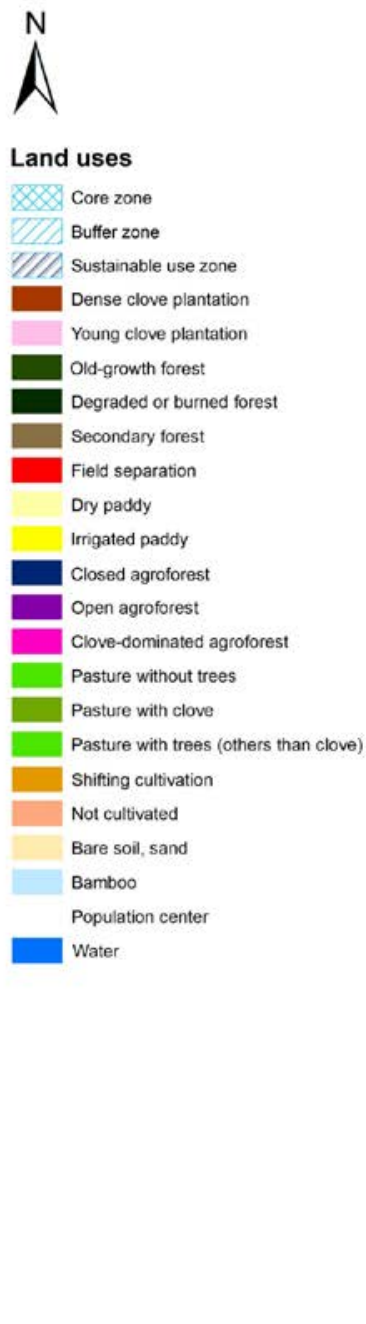


\subsection{Evolution of agricultural systems from 1990 to 2017}

In general, the two study landscapes present similar trends of land use evolution from 1990 to 2017 (Figure 4), albeit of a different pace and extent. While old-growth forest is still the dominant land cover in both sites, its extent declined by about a third in both landscapes over the study period (Table 5). Forest cover dropped in Beanana from over 87\% in 1990 to $62 \%$ in 2017, and from $76 \%$ to 54\% in Fizono. In parallel, we observe an increasing trend in forest degradation throughout the study period, with a threefold increase in degraded forest in Fizono, and an increase of more than 70 times in Beanana. The surface area devoted to shifting cultivation increased threefold in the case of Beanana, from covering nearly $10 \%$ of the landscape to over 30\%, while in Fizono it increased from 17\% to 27\%. Also, both landscapes show a trend towards secondary forest growth on former shifting cultivation fields since the late 1990s.

Figure 4. Land use transitions of the two study landscapes from 1990 to 2017, with each land use represented as a percentage of the total area for each year. A) Beanana. B) Fizono. 'Other' land uses include: living fence, population centres, bamboo, bare soil, not cultivated, and river.

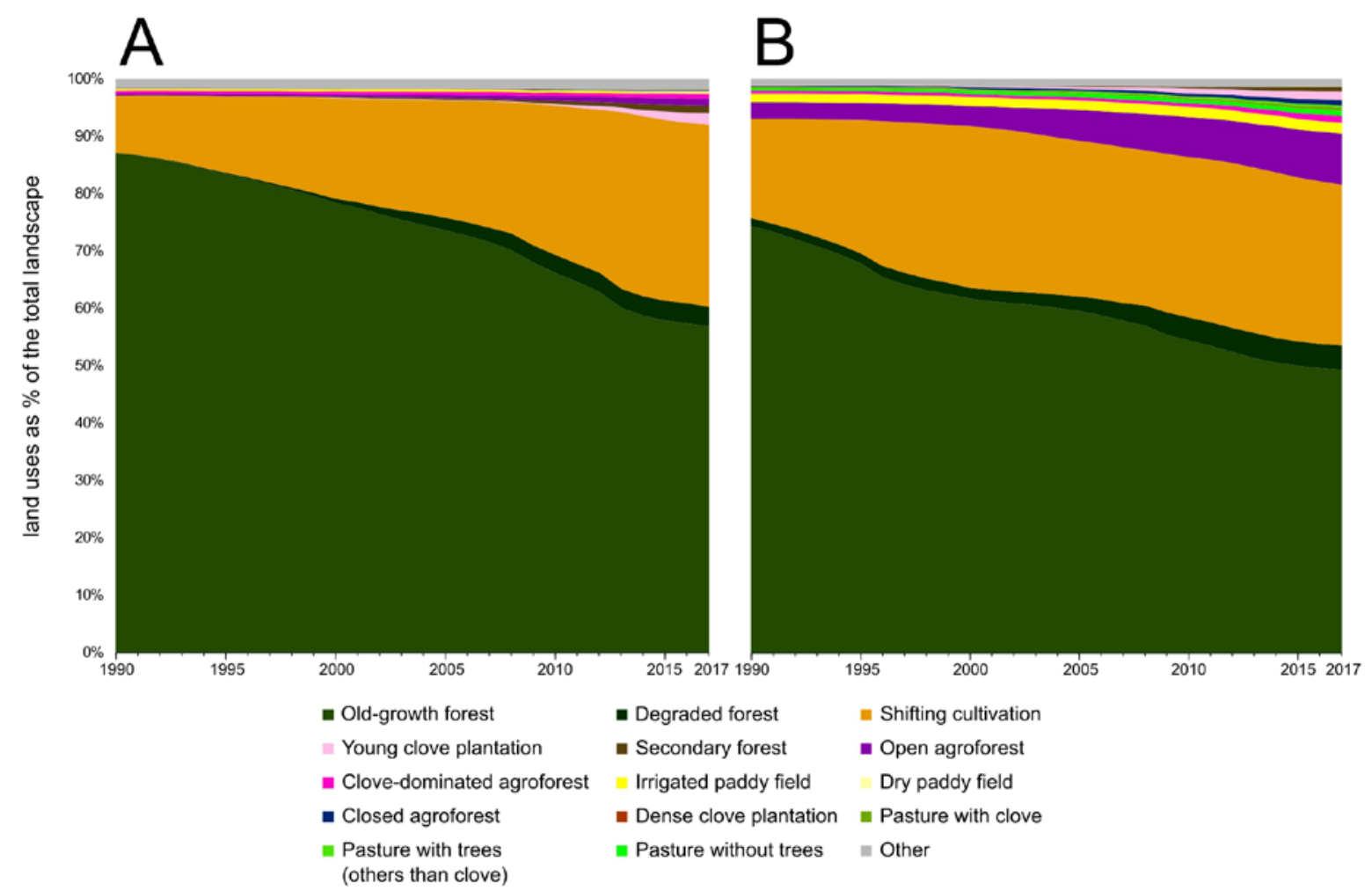

More intensive land uses (i.e. permanent cultivation systems) expanded progressively throughout the study period in both landscapes (Figures 4 and 5). Land uses within the 
agroforestry category (Table 4 ) increased by over $170 \%$ in Beanana, from $0.8 \%$ of the total landscape in 1990 to 2.2\% in 2017; in Fizono, it increased by more than 200\%, from 3.5\% to more than $11 \%$. A particularly staggering development is the increase in clove-related land uses, especially that of young clove plantations, from 0 ha to over 70 ha in Beanana, and from some 2 ha to more than 100 ha in Fizono. In both landscapes, the absolute area of land devoted to irrigated rice cultivation increased by about a third during the studied period. Overall, the more intensive land uses reviewed in this paragraph went from covering $1.3 \%$ and $5.3 \%$ of the total landscape in 1990, to 4.9\% and 15\% in 2017, in Beanana and Fizono, respectively.

Table 5. Total area covered by the different land uses in 1990 and 2017 in hectares, and net change between 1990 and 2017 in percent.

Beanana

Fizono

\begin{tabular}{|c|c|c|c|c|c|c|c|c|c|}
\hline $\begin{array}{l}\text { Land use } \\
\text { category }\end{array}$ & Land use class & $\begin{array}{l}\text { Area } 1990 \\
\text { (in ha) }\end{array}$ & $\begin{array}{l}\text { Area } 2017 \\
\text { (in ha) }\end{array}$ & $\begin{array}{l}\text { \% change } \\
1990-2017\end{array}$ & $\begin{array}{c}\text { \% change } \\
\text { aggregated }\end{array}$ & $\begin{array}{l}\text { Area } 1990 \\
\text { (in ha) }\end{array}$ & $\begin{array}{l}\text { Area } 2017 \\
\text { (in ha) }\end{array}$ & $\begin{array}{l}\% \text { change } \\
1990-2017\end{array}$ & $\begin{array}{c}\text { \% change } \\
\text { aggregated }\end{array}$ \\
\hline \multirow{2}{*}{ Forest } & Old-growth forest & 3283.6 & 2144.3 & $-34.7 \%$ & \multirow{2}{*}{$-29.3 \%$} & 5333.1 & 3537.5 & $-33.7 \%$ & \multirow{2}{*}{$-28.3 \%$} \\
\hline & Degraded forest & 1.8 & 127.8 & $+7144.1 \%$ & & 97.2 & 305 & $+213.9 \%$ & \\
\hline \multirow{3}{*}{ Clove } & $\begin{array}{l}\text { Dense clove } \\
\text { plantation }\end{array}$ & 2.7 & 2.8 & $+4 \%$ & \multirow{3}{*}{$+2231.7 \%$} & 2.9 & 3.6 & $+25.8 \%$ & \multirow{3}{*}{$+692.8 \%$} \\
\hline & $\begin{array}{l}\text { Young clove } \\
\text { plantation }\end{array}$ & 0 & 74.9 & --- & & 1.8 & 102.3 & $+5507.1 \%$ & \\
\hline & Pasture with clove & 0.7 & 1.9 & $+179.8 \%$ & & 14 & 42.6 & +203.5\% & \\
\hline \multirow{3}{*}{ Agroforest } & $\begin{array}{l}\text { Clove-dominated } \\
\text { agroforest }\end{array}$ & 19 & 30.3 & $+58 \%$ & \multirow{3}{*}{$+170.9 \%$} & 37.3 & 85.6 & $+129.4 \%$ & \multirow{3}{*}{$+213.1 \%$} \\
\hline & Close agroforest & 0 & 7.4 & --- & & 9.3 & 68.1 & +628.3\% & \\
\hline & Open agroforest & 12.1 & 46.5 & $+285.4 \%$ & & 206.1 & 637.9 & $+209.4 \%$ & \\
\hline \multirow[b]{2}{*}{ Pasture } & $\begin{array}{l}\text { Pasture without } \\
\text { trees }\end{array}$ & $<0.1$ & 0.6 & $+2061.8 \%$ & \multirow[b]{2}{*}{ +1567\% } & 22.8 & 66.1 & +189.9\% & \multirow[b]{2}{*}{$+161.1 \%$} \\
\hline & $\begin{array}{l}\text { Pasture with trees, } \\
\text { no clove }\end{array}$ & $<0.1$ & 0.7 & $+1296 \%$ & & 11.6 & 23.7 & $+104.5 \%$ & \\
\hline Other & Population center & 3.1 & 5.6 & $+81 \%$ & $+33.1 \%$ & 6.1 & 9.3 & $+51.4 \%$ & $+23.2 \%$ \\
\hline
\end{tabular}


Figure 5. Evolution of land uses as a \% of the total landscape from 1990 to 2017. A) Beanana. B) Fizono. Only land uses covering, by 2017, between $<2 \%$ and $>0.2 \%$ or $>0.6 \%$ of the landscapes in Beanana and Fizono respectively are displayed. The upper threshold equals 75.3 ha in Beanana and 143.3 ha in Fizono. Sources: clove prices, FAOSTAT. Vanilla prices, Terazono (2017), Eurovanilla, Nielsen-Massey. Note that the scale for both type of values in the right $y$-axis is the same.
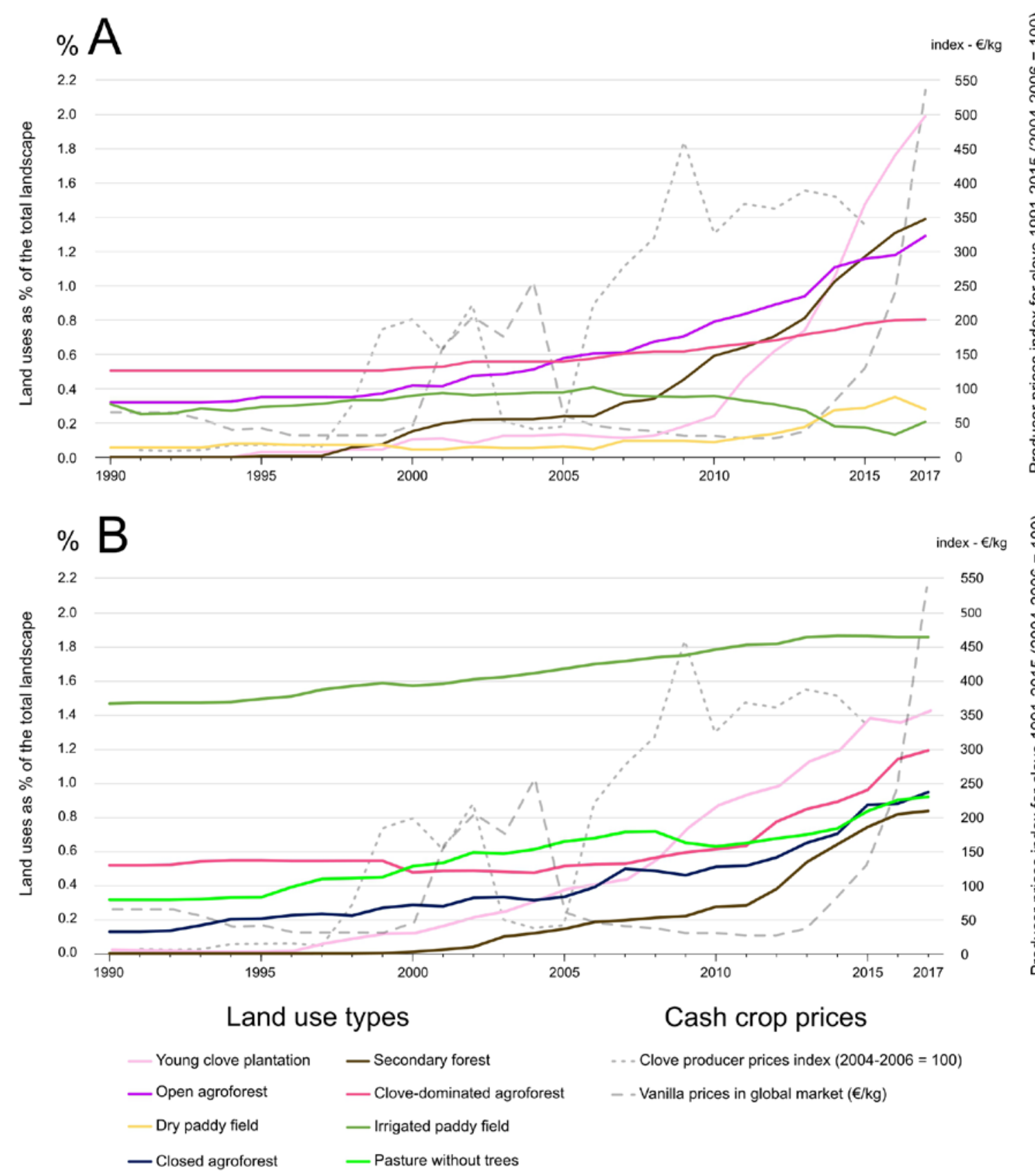

\subsection{Land use trajectories of agricultural expansion}

Looking at the from-to land use trajectories (Figure 6; see SI 1 for details on how to interpret Figure 6), the bulk of agricultural expansion in our landscapes during the study period was achieved at the expense of old-growth forest. Forests that were cleared to create fields for shifting cultivation accounted for $98.5 \%$ of total forest loss in Beanana and 91.2\% in Fizono, 
while the rest comprised direct conversion of forest into other land uses, mainly agroforest. The rate of mean annual deforestation was thus 1.3\% (Beanana) and 1.2\% (Fizono) from 1990 to 2017, although we found distinct temporary trends in the two landscapes (Figure 7).

Figure 6. Evolution of major from-to land use trajectories in the two study landscapes, and major events from 1990 to 2017. A) Beanana. B) Fizono. The graphs only display the plots whose land use changed at least once during the study period, and from these, only land use changes that involved at least 30 ha accumulated throughout the period in the case of Beanana, or 100 ha in the case of Fizono.
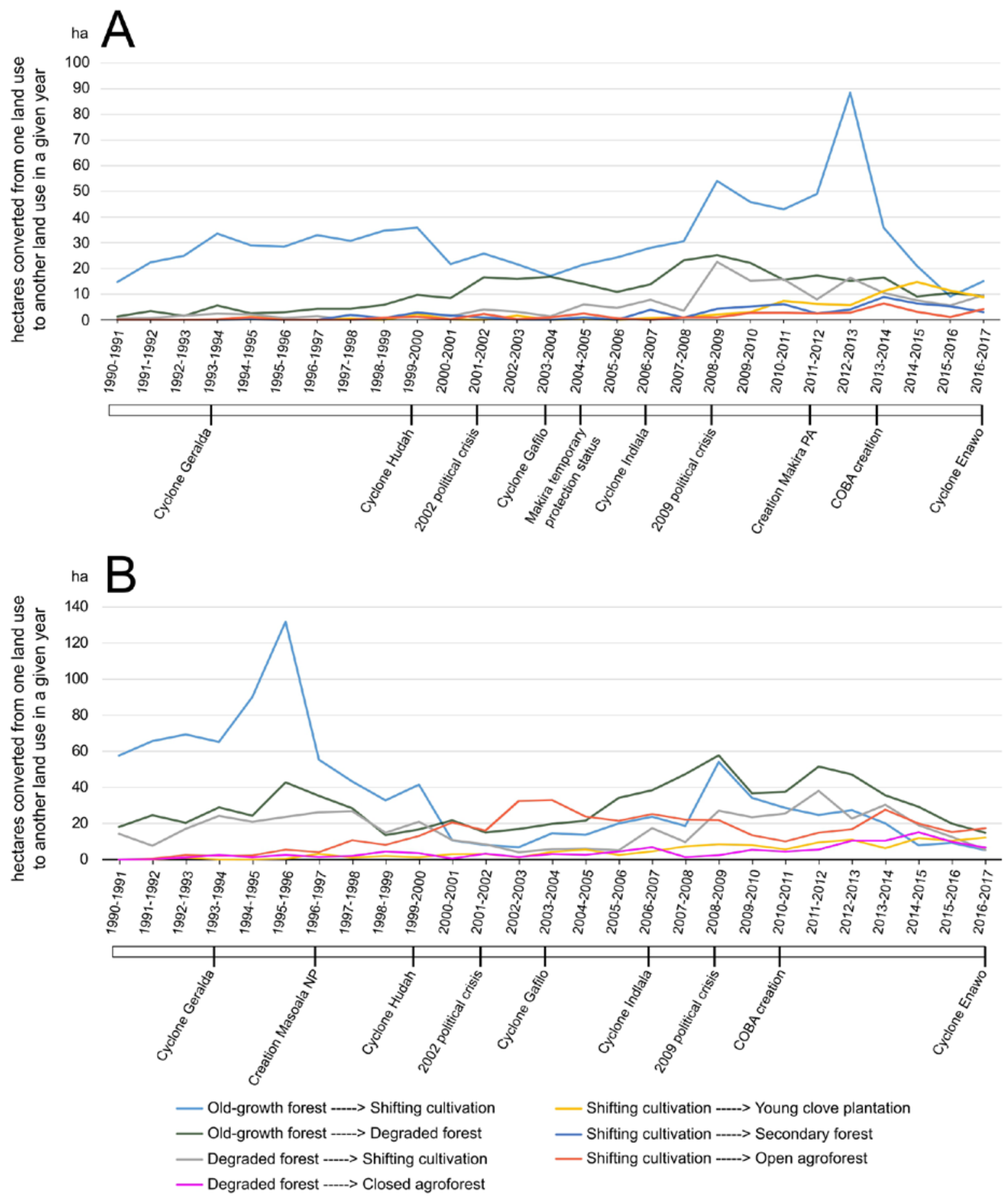
In Beanana, conversion of old-growth forest into shifting cultivation remained relatively stable, hovering at around 30 ha per year for most of the 1990s and then decreasing slightly until about 2005 (Figure 6). A steady rise in rates of forest conversion to shifting cultivation occurred between 2005 and 2009, with a drastic increase between 2009 and 2010 . Conversion rates then decreased again, only to rebound in 2012, hitting the highest rates of forest loss - over 4\% - in the studied period between 2012 and 2013 (Figure 7). From 20142015 onwards, conversion drastically decreased, with annual deforestation rates in 2016 and 2017 remaining below 1\%. In terms of forest degradation, the temporal dynamics in Beanana remained relatively stable, at less than $0.2 \%$ of annual mean forest degradation up to the early 2000s. It then began a slow increase, peaking in 2009, and then decreasing steadily up to 2017.

Figure 7. Annual deforestation and forest degradation rates 1991-2017.

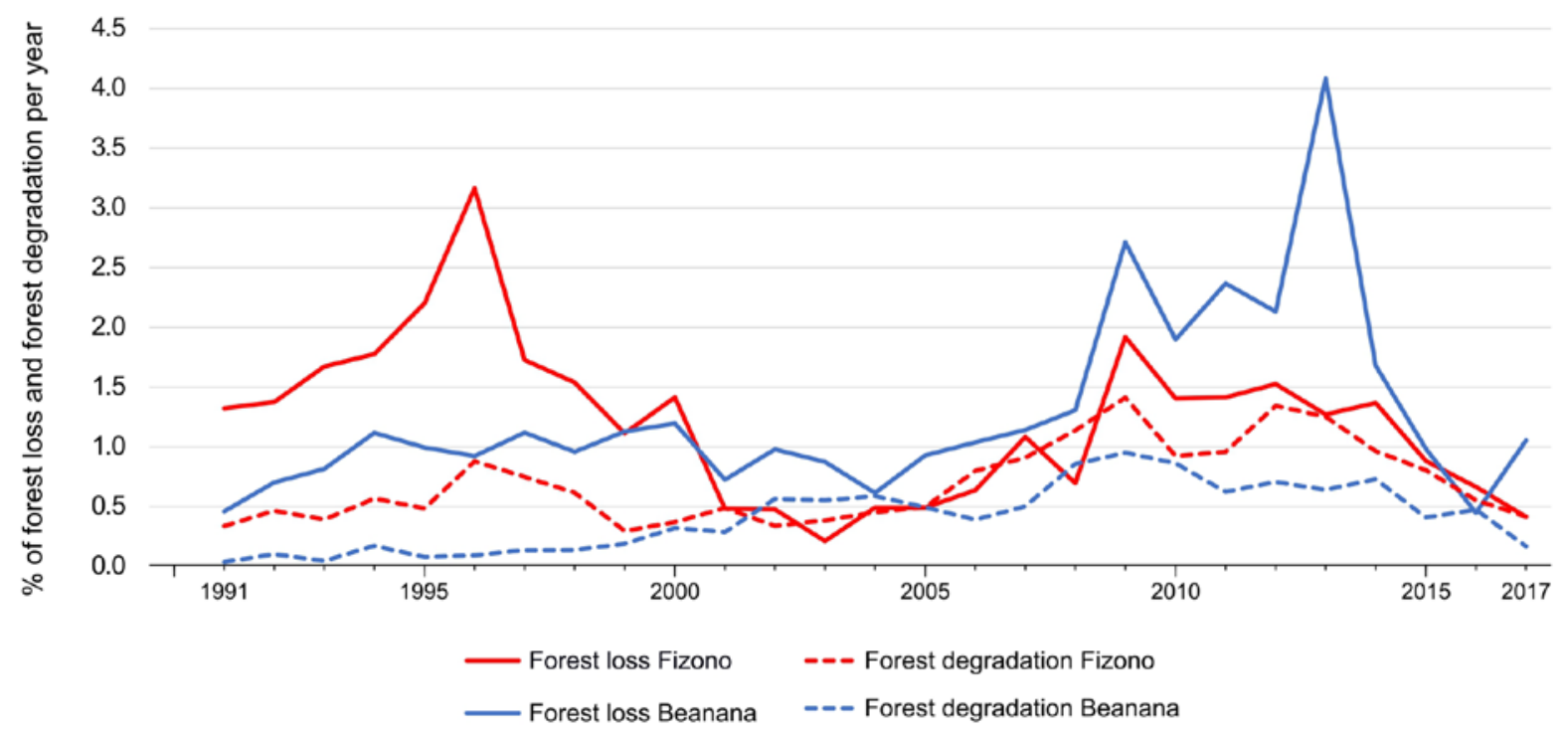

Fizono's overall trajectory is comparable, albeit with significant differences in the 1990s compared to Beanana. Old-growth forest in Fizono was converted into shifting cultivation at a pace of 60-70 ha annually between 1990 to 1994, corresponding to an annual forest loss rate of $1.5 \%$. However, forest conversion increased significantly in the following years, exceeding a deforestation rate of 3\% in 1996 (Figure 7). Thereafter, the rate dropped drastically, remaining well below $1 \%$ throughout the 2000s, with the remarkable exception of the years 2000 and, like in Beanana, 2009. In the first half of the 2010s, deforestation rates remained substantially higher than in the previous decade; then they dropped back to below or around $1 \%$ in recent years. 


\subsection{Agricultural intensification dynamics at the landscape level}

In the following paragraphs, we present the temporally dense trajectories of the land use categories we consider indicative of agricultural intensification in this study, namely cloverelated land uses, agroforest land uses, and paddy rice (Table 3). To obtain further insight, we explore the development of some of these land uses in relation to cash crop prices over the last three decades: concretely, we examine young clove plantations and the clove producer price index for 1991-2015, as well as agroforest in regard to vanilla prices on the global market in 1990-2017 (Figure 5).

The extent of clove-related land uses (Table 3) mostly remained stable throughout the 1990s in both Beanana and Fizono (Figure 5), with fields existing throughout this period mostly accounted for by plots that had been used that way for several decades. However, as of 19951997, young clove plantations slowly expanded in both study landscapes, seemingly following the slight increase in prices witnessed since 1993, albeit with a 1-3-year delay. Later, during the clove price 'boom' between 1998 and 2002, the area devoted to young clove plantations was further expanded, particularly in Fizono. When clove producer prices collapsed between 2003 and 2005, expansion of young clove plantations in Beanana halted, and their area remained stable for most of the 2000s, while in Fizono this expansion continued, albeit with a slowdown between 2005 and 2007. The rise in clove prices as of 2006 was followed by a marked increase, several years later, in the area devoted to young clove plantations. In Beanana, the surface area of young clove plantations increased tenfold in just a decade, reaching nearly 75 ha in 2017, its growth outpacing that of any other land use in this landscape except shifting cultivation. In Fizono, this trend has been discernible since 2007, with a nearly threefold expansion of young clove plantations and pasture with clove in the following years, reaching over 100 ha devoted to the former land use by 2017.

The extent of the three agroforestry land use classes (Table 3) in both study landscapes remained stable throughout the 1990s (Figure 5). However, in the next decade, the short-lived vanilla boom between 2001 and 2004 was paralleled by an increase in the extension of open agroforest in both study landscapes, albeit with slightly different timing. In Beanana, the trend is visible between 2002 and 2005 (Figure 5), when open agroforestry surpassed clovedominated agroforestry, up to then the most widespread agroforestry type in the landscape. In Fizono, the trend was more prominent between 2001 and 2004, and indeed, for much of the 2000s, conversion of shifting cultivation fields into open agroforest was the most important land use trajectory by area, with over 20 ha converted annually in most years (Figure 6). When 
prices for vanilla dropped again between 2005 and 2013, the expansion of agroforest slowed down, although it continued in both landscapes. The current vanilla boom, which started in 2013, coincided again with an acceleration of the expansion of open agroforest, clearly visible in both landscapes from 2014 onwards.

Finally, in regard to the third major land use category we employ as an indicator of agricultural intensification at the landscape level in this study - paddy rice - we observe an increase of some $30 \%$ in the surface devoted to this land use in both landscapes (Table 5 and Figure 5). However, while in the case of Fizono the increase in paddy fields constituted a 'net' gain in terms of actually irrigated fields, in the case of Beanana we find a different picture. The overall area devoted to paddy rice cultivation in this landscape increased, but the area irrigated decreased by a third, while the area of dry paddy, standing for plots with irrigation or fertility problems, increased fivefold. While this trend has been witnessed since the mid-2000s, it has accelerated in recent years, to the point that by 2014 the total area of paddy fields not cultivated because of water or fertility problems exceeded the area of paddy fields actually being cultivated.

Thus, the bulk of the landscape-level agricultural intensification observed in our study landscapes throughout the last three decades did not involve forest land. Instead, it derived from the conversion of shifting cultivation fields into either agroforestry plots (Figure 6) or clove-related land uses. These land use trajectories, together with conversion of fallow shifting cultivation fields into paddy fields and intensification of agroforestry and pasture by introducing clove trees, account for a total of $88 \%$ (Beanana) and $81.3 \%$ (Fizono) of agricultural intensification processes. However, recent years have seen an emerging tendency towards direct conversion of old-growth or degraded forest into agroforestry plots. This is particularly the case in Fizono, where over 125 ha of forest were directly converted into agroforestry plots without the intermediary step of shifting cultivation. This happened mainly in the mid-2000s and from the mid-2010s up to 2017, coinciding with the overlap in the vanilla and clove booms. In the case of Beanana, the trend is incipient, with some 10 ha of forest converted into agroforest, mostly since 2008.

\section{Discussion}

In the following paragraphs, we discuss the results in the light of our study objectives. We first assess the current situation of our study landscapes in the overall land use transition, and then move on to explore the influence of the key factors stressed by participants as 
influencing their land use decisions. These land use decisions concern agricultural expansion and intensification, which we examine by looking at the temporally dense land use trajectories and change spikes which at the aggregate level make up the land use transitions. To inform the discussion, we draw on the qualitative information conveyed by participants in this study, and look at other cases from other world regions with comparable agricultural processes in shifting cultivation landscapes.

\subsection{Land use transitions: prevalence of shifting cultivation amidst intensifying agriculture}

According to land use transition theory (DeFries et al., 2004; Foley et al., 2005), both study landscapes are at a relatively early stage; Beanana even more so than Fizono. In Beanana, we still observe a strong presence of forest clearings in recent years for the expansion of subsistence agriculture through pioneer shifting cultivation; although we also see an incipient trend of agricultural intensification (Figures 4-7). Fizono is more advanced in the transition, with forest clearing rates decreasing since the early 2000s, and agriculture being more intensive at the landscape level. Despite these slight differences, the two landscapes present a similar overall picture: While shifting cultivation might be declining in importance in the landscape dynamics, it continues to play a key role in local communities' subsistence practices (slightly more so in Beanana than in Fizono).

These results are at odds with findings from other regions of continental Africa, where shifting cultivation systems are in decline (Kilawe, Mertz, Silayo, Birch-Thomsen, \& Maliondo, 2018), or from other world regions, where until recently this system has played a central role in local livelihood strategies and land cover dynamics, as in both mainland and maritime South-East Asia (Mertz et al., 2009; van Vliet et al., 2012). Rather, in our landscapes, shifting cultivation coexists with increasing intensity of agriculture - a situation found in other contexts as well (Cramb et al., 2009; Grogan, Birch-Thomsen, \& Lyimo, 2013). Such coxistence of shifting cultivation and intensive commercial or subsistence agriculture can last for decades, as has been reported for other areas of north-eastern Madagascar (Laney, 2002; Laney \& Turner, 2015). Key explanations are the safety net role that shifting cultivation plays within farmers' livelihood portfolios to buffer against cash crop price fluctuations (Cramb et al., 2009; Osterhoudt, 2016), or the relatively higher return to labour input it offers compared to other subsistence activities like irrigated rice cultivation (Laney, 2002). Other reasons relate to the ease of accommodating the seasonal timing of shifting cultivation tasks between other 
agricultural activities (Cramb et al., 2009), or even the cultural preference for the taste of shifting cultivation rice (Laney, 2002).

These four points were confirmed by local farmers participating in our study, who considered shifting cultivation to be a labour-efficient subsistence activity that complemented their other livelihood strategies in an essential way. It was especially important to ensure food security in the event of a crash in cash crop prices, as demonstrated recurrently in connection with the unpredictable behaviour of vanilla and clove prices in the last three decades (Figure 5). Furthermore, despite the existence of peak times for labour needs in the local agricultural calendar, farmers stated that the key tasks involved in shifting cultivation were temporally flexible enough to be completed between those required for the other main crops in the area, particularly when they could rely on extended family and a network of acquaintances. Finally, local participants recurrently highlighted the preference for self-produced rice, particularly compared to the other option of spending their cash crop revenue on buying imported rice from the local market. A further factor that can help explain the difference in shifting cultivation prevalence between the two landscapes is their different degree of remoteness. Remoteness has consistently been found to be a relevant factor explaining different degrees of reliance on shifting cultivation in landscapes traditionally dominated by this agricultural system, for example in northern Laos (Castella et al., 2013; Heinimann et al., 2013). Consistent with these findings, the more remote landscape of Beanana shows a more protracted presence of this agricultural system throughout the last three decades and up to 2017.

Finally, while we acknowledge that our understanding of secondary forest in this study (see SI 1) demands caution when interpreting this result, forest regrowth appears to have begun and accelerated since the late 1990s and the early 2000s in Fizono and Beanana, respectively. However, it seems too early to interpret this as signals of a forest transition (Meyfroidt \& Lambin, 2011) taking place, as forest loss still largely outpaces forest gain in both landscapes. This result diverges from findings across tropical Africa, where landscapes with significant presence of shifting cultivation have begun to undergo forest transitions (Käyhkö, Fagerholm, \& Mzee, 2015), as well as in the central highlands of Madagascar, where an incipient forest transition has recently been documented (McConnell et al., 2015). 


\subsection{Agricultural expansion: forest loss, PAs, and transfer of management rights to local Populations}

Some of the temporal dynamics of land use trajectories leading to agricultural expansion in our study landscapes - which, as shown, occurred overwhelmingly at the expense of forest land - reflect trends also witnessed in other areas of Madagascar. This is the case, for example, of the low forest clearance rates in both landscapes during much of the 2000s (Figure 6), which coincided with a period of low deforestation reported for other regions in the country (ONE, DGF, FTM, MNP, \& CI, 2013), arguably related to the relatively stable political climate and the push to extend forest conservation schemes by Marc Ravalomanana's government (Gorenflo et al., 2011). However, and more interestingly, land use change trajectories and timing of the main spikes in forest loss in Beanana and Fizono suggest that the establishment of the two PAs and the transfer of forest management rights in their buffer zones to local communities influenced the dynamics of our two study landscapes, although in unexpected ways.

For example, in the case of Beanana, the period of relatively low deforestation observed in the first half of the 2000s began, in 2005, to give way to a steady increase in forest-to-shifting cultivation conversion (Figure 6). The start of this trend coincided with the date on which temporary protection status was granted to Makira as an NPA, which was followed from 2006 onwards by the gradual transfer of management rights for its buffer zones to communities living in the periphery of the park in other sectors. According to the park managers we interviewed for this study, in the case of communities in the southern sector of Makira, where Beanana is located, the transfer of management rights did not materialize until a later stage, for two interrelated reasons.

The first is the remote location of this site, particularly from the district capital further north, Maroansetra, where the park administration headquarters are located. Unlike communities in the south, rural populations closer to Maroansetra were already accustomed to collaborating with Makira's project staff since the early 2000s, when the project started activities in the most accessible areas closer to the district capital; this likely facilitated the early and comparatively smoother transfer of management rights to these communities. The second, arguably related, reason why the transfer of management rights did not take place in Beanana until 2014, is that this community was protractedly reluctant to collaborate with park administrators and staff.

Information from the interviews and workshops we conducted in Beanana did not enable us to confirm unequivocally the relation between the increasing trend of forest clearing 
observed in this landscape since 2005 (Figure 6) and the implementation of the NPA in December of the same year. Nonetheless, this trend is suggestive of the emergence of a 'leakage effect' (Meyfroidt et al., 2018). A leakage effect is the unintended land use spillover caused by an environmental management intervention leading to the displacement of land use change elsewhere. In the case of Pas implemented to halt forest loss, a leakage effect would consist in PA establishment encouraging deforestation outside of the protection scheme boundaries. Although this needs to be further researched in Beanana, the phenomenon has been well documented for PAs elsewhere in the world (Ewers \& Rodrigues, 2008; Oliveira et al., 2007). It has also recently been explored using panel data in eastern Madagascar (Desbureaux, Kéré, \& Combes Motel, 2016). Nonetheless, the highest rates of forest conversion in the entire period for Beanana’s landscape were registered at a later stage, between 2012 and 2014 (Figure 6), when deforestation rates attained over 4\% (Figure 7). In 2012, Makira was established as a fully fledged PA, with local authorities required to sign documents recognizing the new full protection status of the forests surrounding Beanana. In 2014, the local COBA was created in Beanana, and it was to this newly introduced institution that management rights for the PA buffer zone in the area were transferred.

While the spike in deforestation in Beanana following the establishment of Makira as a PA in 2012 could account for a reinforced leakage effect, another phenomenon might also have played a significant part in the dynamics of this landscape: that of pre-emptive behaviour by local farmers. Pre-emptive behaviour in this context refers to an exacerbation of resource extraction efforts in anticipation of a shift towards more restrictive policies on access to natural resources (Brown, Brown, \& Brown, 2016; Ceddia \& Zepharovich, 2017; Nolte et al., 2018), in some cases linked to expected future conflicts over natural resources (Aldrich, Walker, Simmons, Caldas, \& Perz, 2012). In the case of Beanana, farmers would have converted forest into shifting cultivation fields in order to secure agricultural land before the creation of the COBA and the transfer of management rights in 2014, which introduced substantially more restrictive management regulations for the forests surrounding the PA. This strategy would have been facilitated by the 'right-of-axe' (Blanc-Pamard, 2009), which prevails in much of Madagascar, including our region, and which confers customary tenure rights on the person who clears the forest. Such pre-emptive forest conversion has been reported in southern Madagascar, where, in advance of an imminent land registration programme, farmers cleared forest to be able to claim occupation of the land through customary regulations and be eligible for formal title to the land they had recently cleared (Middleton, 2013). To our knowledge, there is no scientific evidence so far of this pre-emptive behaviour in relation to implementation 
of terrestrial PAs, although it was recently proven through a counterfactual impact approach in the case of marine PAs in the Pacific (McDermott, Meng, McDonald, \& Costello, 2018), and has also been found to have occurred as a consequence of conflict over land in contexts of contentious land tenure situations in the Brazilian Amazon (Aldrich et al., 2012). A further explanation of the relation between the unprecedented spike in deforestation, the establishment of Makira PA, and the transfer of management rights for the buffer zone to local communities might be related to the animosity towards park activities shown by a sector of the local population in our study area. This could point to the potential use of deforestation as a tool of protest against the establishment of the PA; a similar interpretation has been suggested in the central highlands of Madagascar, where grasslands were burnt in protest as conservation activities began (Kull, 2004). Our fieldwork revealed that much of the population in the area accepted the creation of the local COBA as a fait accompli, and that many felt they were losing out in regard to the PA; this would support the last point.

In the case of Fizono, a comparable phenomenon of pre-emptive forest clearance appears to have preceded implementation of Masoala NP, although earlier and in accordance with the timing of the establishment of this PA in 1997 (Figure 7). The two immediately preceding years, 1995 and 1996, showed the highest deforestation rates recorded during our study period. In this case, local participants confirmed that as soon as local farmers started receiving the news about the creation of a strict forest conservation scheme in the forests surrounding their village, they rushed to clear as much land as they could in order to acquire user rights. A similar situation has been reported for another area of Masoala further south, this time in the first half of the 1990s (Keller, 2015). Furthermore, shortly after the PA was established, a significant lack of knowledge about the exact location of the park boundaries was found among local villagers in our area (Ormsby \& Kaplin, 2005). This finding highlights the importance of unambiguous and widespread communication of plans for PAs to local populations, to avoid such unintended consequences and to make it easier to obtain local approval for protection schemes, as has been shown in the case of marine PAs in the Philippines (Knight, Mendezona Allegretti, \& Vaske, 2015).

However, sharply decreasing deforestation rates after the PA was established in Fizono demonstrated the effectiveness of this environmental intervention in halting forest loss, as was shown recently for many other regions in Madagascar (Eklund et al., 2016). While PA establishment did not have the same effect in Beanana, here it was the creation of the local COBA and the subsequent transfer of responsibility for forest management and enforcement of forest regulations in the buffer zone which appears to have markedly slowed down forest 
clearance after 2014. A similar effect is visible in Fizono after 2011, when the local COBA was created there (Figure 6). These findings are in line with those of other studies in eastern Madagascar, which have highlighted the transfer of resource management rights to local communities as a potentially sound tool to support sustainable use of natural resources, for example in the case of freshwater resources harvesting (Jones, Andriahajaina, Ranambinintsoa, Hockley, \& Ravoahangimalala, 2006) or wildlife exploitation (Keane, Ramarolahy, Jones, \& Milner-Gulland, 2011).

However, only transferring forest resource management to local communities may not be sufficient to achieve sustained conservation in the long run, as suggested by other research conducted in the country (Casse \& Milhøj, 2012; Raik \& Decker, 2007). Contrarily, new, more restrictive rules on access to forest resources can burden local communities, particularly in the absence of complementary local development measures. Indeed, this was repeatedly stressed by farmers in our workshops, interviews, and informal conversations in the villages, particularly in Beanana, and it contributes to farmers' growing perception that they are losing out in regard to the PAs, which can end up backfiring on conservation efforts. This is in line with other studies in Makira PA and Masoala NP that found greater support for conservation interventions among populations who had positive perceptions towards the parks, most often related to the implementation of PA-related development projects in their villages (Marcus, 2001; Ratsimbazafy, Harada, \& Yamamura, 2012).

\subsection{Agricultural intensification: induced intensification, cash crop booms and further pressure on forests}

In regard to the intensification processes discussed above, and in spite of the broad similarity of some general dynamics in the two study landscapes, there are several important differences in the land use trajectories worth exploring.

One difference is the accelerating trend of conversion of shifting cultivation fields into young clove plantations since 2007 (Figure 5). While a steep rise was recorded at both sites, the outcome at the landscape level differed substantially. In Fizono, the cover of young clove plantations rose from $0.4 \%$ to $1.4 \%$ of absolute landscape area over the last decade; in Beanana, the corresponding rise was from $0.1 \%$ to $2 \%$. A broad explanation for the difference in the extent and pace of agricultural intensification is the following. As suggested in relation to the land use transitions discussed above, farmers in Fizono might have succeeded much earlier in finding a balance between food provision through subsistence agriculture based on shifting cultivation and paddy rice production, on the one hand, and income generation through 
commercial agriculture based on agroforest and clove production, on the other. One reason for this may be that, at the beginning of the study period, the degree of agricultural intensification at the landscape level in Fizono was substantially higher than in Beanana. Another possibility is that agricultural intensification processes were felt more strongly in Fizono than in Beanana in the first decades of the study period, concretely during the first vanilla and clove booms in the mid-2000s. This would help to explain why, even in a context of growing prices for clove, expansion of clove-related land uses was much less pronounced in Fizono than in Beanana, as the former landscape already had a large area dedicated to such land uses.

Fizono’s earlier trend of intensification, also visible for agroforest land uses (Figure 6), might be explained by several factors. First, early establishment of the PA may have induced agricultural intensification by preventing further expansion of agricultural fields into the forest. This has been found in other areas in the tropics (Kim Chi et al., 2013) and in the same region of Madagascar (Laney, 2002). This hypothesis is further supported by the fact that even decreasing prices for cash crops never completely halted conversion of shifting cultivation fields into agroforest and clove-related land uses in this landscape after the PA was established (Figure 6). In Beanana, agricultural intensification accelerated from the second half of the 2000s onwards, when Makira was established as an NPA and forest resource management rights were progressively transferred to local populations elsewhere. The combined effect of the looming prospect of stricter forest protection in the near future and increasing prices for cash crops might have induced farmers to intensify their agricultural practices. Supporting the hypothesis that PA establishment induced intensification is the fact that agricultural intensification trajectories in Beanana were especially pronounced most recently, when Makira was granted full protection, management rights for the buffer zone were transferred to local communities, and prices for both clove and vanilla boomed (Figures 5 and 6).

However, a parallel finding that points to challenges in the effectiveness of the PAs and management rights transfers to avoid deforestation is the emerging trend of direct conversion of forest into agroforest, particularly in Fizono, in parallel with the recent price increases for vanilla and clove. As has been found in other cases in the humid tropics, the boom-and-bust nature, that is often inherent in the global agricultural commodities trade in telecoupled situations, may have profound implications for forest dynamics (Vongvisouk, Broegaard, Mertz, \& Thongmanivong, 2016). This relates to the rebound effect (Meyfroidt et al., 2014), where, amid increasing prices for cash crops, farmers not only intensify their agricultural practices, but also expand their fields into uncultivated land to benefit from the commodity boom while it lasts. This dynamic corresponds to the Jevons paradox (Alcott, 2005; 
Andriamihaja, Metz, Zaehringer, Fischer, \& Messerli, 2019; Hill, Miller, Newell, Dunlop, \& Gordon, 2015; Jevons, 1865), which posits that gains in efficiency of the use of a given production factor might promote, rather than diminish, its use. Our finding mirrors examples from other world regions, where market-driven agricultural intensification through increased prices for export agricultural commodities has been suggested to have encouraged deforestation (Byerlee et al., 2014). Indeed, recent reviews have shown that in the case of the land production factor in the tropics, increases in productivity or value often encourage conversion of forest to agricultural land (Ceddia, Bardsley, Gomez-y-Paloma, \& Sedlacek, 2014; Rasmussen et al., 2018). This phenomenon poses a challenge to the land sparing hypothesis, which argues that preserving biodiversity while intensifying agriculture can be better achieved by spatially segregating agricultural production from strict nature conservation land uses (Green, Cornell, Scharlemann, \& Balmford, 2005). It can even result in escalating forest conservation costs (Phelps, Carrasco, Webb, Koh, \& Pascual, 2013).

A last remark on the main agricultural intensification pathways we explored in this study concerns our findings on the expansion of paddy rice fields (Figure 5). As we saw, Fizono tended towards a steady net increase in irrigated paddy fields throughout the study period, chiefly on those shifting cultivation fields that were amenable to irrigation - a trend particularly visible since the late 1990s when the PA was implemented in this landscape. By contrast, farmers in Beanana highlighted unintended outcomes of complex interactions between different land use change dynamics, as well as, critically, a lack of means for putting in place irrigation schemes in flat areas. Farmers in Beanana related the decreasing availability of water to irrigate their rice fields to expansion of shifting cultivation into the forest, referring specifically to the recently cleared sections of the landscape surrounding the paddy fields. Moreover, villagers said that decades ago, large flat areas on the banks of some of the streams in Beanana had been irrigated for several years, until the irrigation scheme broke down; lack of means to repair it had then forced them to grow rice under a shifting cultivation regime. While these environmental constraints might help explain why shifting cultivation is still so prevalent in Beanana compared to Fizono, as suggested for other world regions (Cramb et al., 2009) and also north-eastern Madagascar (Laney, 2002), the villagers' account also points to an untapped potential for irrigation and a possible pathway towards agricultural intensification - and, arguably, towards reducing pressure on forest resources, as participants in our study recurrently remarked. 


\subsection{The role of discrete events in land use trajectories: cyclones and political crises}

In addition to the continuous trends just reviewed, during our participatory fieldwork local farmers highlighted two key types of discrete events that significantly influenced their land use decision making during the study period: cyclones and political unrest.

Regarding cyclones, it has been suggested for Madagascar that these extreme weather events might encourage forest conversion as an indirect consequence of their impact on vulnerable populations (Llopis, 2018; Urech, Zaehringer, Rickenbach, Sorg, \& Felber, 2015). In our study landscapes, one of the most prominent examples is Cyclone Hudah (see also Brownell, 2011), whose impact participants in Fizono portrayed as a breaking point in the landscape dynamics. In this area, Hudah’s landfall in April 2000 and subsequent flooding destroyed over 17 ha of agroforest located on the banks of the river Mahalevona, and the strong winds felled clove trees upland (mostly on pasture land, dense plantations, and clovedominated agroforest plots). The demise of these permanent cultivation fields was accompanied in the same and following year by a clearly above average rate of conversion of shifting cultivation fields into agroforest (Figure 6); local farmers said they had tried to make up for the destroyed fields as quickly as possible. In addition, the conversion rate of old-growth and degraded forest into shifting cultivation experienced a notable spike, breaking with the decreasing trend of deforestation experienced there since the establishment of Masoala NP.

Although not as prominently as Hudah, the impacts of several of the cyclones passing through our study landscapes over the last decades overlapped with a slight increase in forest degradation and conversion of forest into shifting cultivation. This is most visible for cyclones Geralda in 1994 and Enawo in 2017 in the case of Beanana, and for Gafilo in 2004 and Indlala in 2007 in Fizono (Figure 6).

While these findings are not conclusive and more research is needed to further explore these relationships, the overlapping occurrence of cyclones with periods of increased deforestation may point to a strategy of farmers clearing forest land to make up for agricultural fields destroyed by cyclones, as shown in other areas of Madagascar (Llopis, 2018; Urech et al., 2015). A further explanation might be that cyclones discourage farmers from engaging in agricultural investments, such as conversion into more intensive land uses that are more vulnerable to these climatic extremes. As remarked by participants in our workshops and also suggested by other research in Madagascar (Danthu et al., 2014; Minten et al., 2006), this could be the case for irrigated paddy rice fields, which are highly susceptible to damage by cyclonedriven floods, or clove fields, which are very sensitive to heavy winds. 
Finally, workshop participants also highlighted the interplay between unforeseen moments of political and social unrest, the related weakening of law enforcement activities, and land use dynamics. The sharp increase as of 2009 in forest degradation and forest conversion into shifting cultivation in both landscapes (Figure 6) coincided with the political crisis that culminated in President Marc Ravalomanana being deposed and forced into exile in March of that year. The transition period from the start of the crisis in 2009 to late 2013, when new presidential elections were held, was marked by a drastic shrinkage in the Malagasy state's capacity to ensure basic functions, not least because international donors halted economic support to a government they did not recognize. This resulted in the erosion of law enforcement measures, particularly felt around PAs, which is believed to have facilitated the significant increase in illegal rosewood logging in the forests of our study region, Makira and Masoala, in this period (Randriamalala \& Liu, 2010; Waeber et al., 2018). In terms of agricultural expansion into forest land in our study landscapes, from 2009 to 2013 we observe substantially higher rates of forest loss and degradation than in the years before and after (Figures 6 and 7). Although farmers in our study villages refrained from overtly supporting this relation, arguably because of the issue's high sensitivity, they suggested in a veiled manner that some households in the villages would have considered those years as a window of opportunity to expand their agricultural fields. This has also been suggested for our region by other studies (Zaehringer et al., 2016), and similar findings have been made in the western and central regions of the island, where record deforestation rates were registered during periods of civil unrest and weak governmental control, such as the early 1990s, 2002-2003, and 2009 (Vågen, 2006; Zinner et al., 2014).

\section{Conclusion}

Our study has shown the potential benefits of combining participatory methods with VHR satellite imagery to map continuous, year-to-year land use change in data-scarce forest frontier landscapes in the humid tropics. The temporally dense spatially explicit information thus co-produced with the local population allowed us to relate land use trajectories with the key continuous trends and discrete events influencing local farmers' land use decisions, which in turn has allowed us to contribute to the development of land use theory.

Concretely, we found that the expansion of subsistence shifting cultivation was widespread over much of the study period and has continued until recently in both landscapes. While contrasting with trends observed in other former shifting cultivation landscapes, this is 
likely due to the role of shifting cultivation as a food security safety net in the face of the price volatility of cash crops. Regarding the effect of PA implementation on land use dynamics, our findings contribute to the expanding body of research on spillover effects, such as displaced deforestation as a consequence of conservation initiatives. However, more significantly, our study is one of the first to provide empirical evidence of pre-emptive deforestation by local farmers ahead of the implementation of terrestrial PAs with forest conservation objectives.

In addition, we have shown that the timing of the main trends in the overall agricultural intensification process observed in our study landscapes during the last decades strongly relates to recent clove and vanilla price booms. Moreover, to a certain extent the diverse trends in intensification also coincide with the timing of the establishment of PAs and the transfer of their buffer zones' management rights to local communities, which possibly points to an induced agricultural intensification process. Further, while we showed that this intensification mainly occurred on former shifting cultivation fields, we also found an increasing trend of direct conversion of forest into agroforest and clove-related land uses over the last decade, which suggests the emergence of a rebound effect. Finally, though only with qualitative data, we have also contributed to the slowly growing body of literature exploring the effect of cyclones and surges of political instability on land use change dynamics.

Given that our study took a mostly descriptive, qualitative approach to explore potential drivers of the land use dynamics we observed in our two study landscapes, our findings must be interpreted with some caution. This is particularly so because in this study we did not explore key aspects like land tenure or land management, which would certainly have provided further insights into the more detailed mechanisms enabling agricultural intensification and regime shifts from landscapes dominated by subsistence shifting cultivation to commercial agricultural systems. Nonetheless, our findings on land use transitions provide a basis for further analytical research on the sustainable development of these landscapes, with relevance also for the broader north-eastern region of Madagascar. Furthermore, the social-ecological outcomes of such land use transitions should be further investigated to understand their implications for ecosystems and livelihoods. Insight on these aspects can reveal the factors supporting sustainable agriculture intensification processes in the humid tropics in the context of PA establishment and cash crop price booms.

\section{Acknowledgments}

The authors warmly thank all participants who contributed to this study for sharing their knowledge with us. The authors would also like to thank the DigitalGlobe Foundation for 
providing the QuickBird 2 satellite imagery used as ancillary data in this study. We also thank the German Aerospace Center for providing the TanDEM-X digital elevation model data ( (C) DLR, 2017) employed in this research. We are grateful to Christoph Bader for the online visualization of the land use change maps, and to Tina Hirschbuehl for editing the manuscript. This research was supported by the Swiss Programme for Research on Global Issues for Development (r4d programme), which is funded by the Swiss National Science Foundation (SNSF) and the Swiss Agency for Development and Cooperation (SDC), under grant number 400440152167.

\section{Disclosure statement}

No potential conflict of interest was reported by the authors. 


\section{References}

Adams, W. M., Aveling, R., Brockington, D., Dickson, B., Elliott, J., Hutton, J., .. . Wolmer, W. (2004). Biodiversity Conservation and the Eradication of Poverty. Science, 306(5699), 1146-1149. doi:10.1126/science.1097920

Alcott, B. (2005). Jevons' paradox. Ecological Economics, 54(1), 9-21. doi:https://doi.org/10.1016/j.ecolecon.2005.03.020

Aldrich, S., Walker, R., Simmons, C., Caldas, M., \& Perz, S. (2012). Contentious Land Change in the Amazon's Arc of Deforestation. Annals of the Association of American Geographers, 102(1), 103-128. doi:10.1080/00045608.2011.620501

Andriamihaja, O. R., Metz, F., Zaehringer, J. G., Fischer, M., \& Messerli, P. (2019). Land Competition under Telecoupling: Distant Actors' Environmental versus Economic Claims on Land in North-Eastern Madagascar. Sustainability, 11(3), 851.

Anonymous. (2018). Rosewood democracy in the political forests of Madagascar. Political Geography, 62, 170-183. doi:https://doi.org/10.1016/j.polgeo.2017.06.014

Bawa, K. S., \& Dayanandan, S. (1997). Socioeconomic factors and tropical deforestation. Nature, 386, 562. doi:10.1038/386562a0

Bertrand, A., Rabesahala-Horning, N., \& Montagne, P. (2009). Gestion communautaire ou préservation des ressources renouvelables: Histoire inachevée d'une évolution majeure de la politique environnementale à Madagascar. VertigO, 9(3), 1-18.

Blanc-Pamard, C. (2009). The Mikea Forest Under Threat (southwest Madagascar): How public policy leads to conflicting territories. Field Actions Science Report, 1-12.

Boillat, S., Gerber, J.-D., Oberlack, C., Zaehringer, J., Ifejika Speranza, C., \& Rist, S. (2018). Distant Interactions, Power, and Environmental Justice in Protected Area Governance: A Telecoupling Perspective. Sustainability, 10(11), 3954.

Brimont, L., Ezzine-de-Blas, D., \& Karsenty, A. (2017). The cost of making compensation payments to local forest populations in a REDD+ pilot project in Madagascar. Madagascar Conservation \& Development, 12(01).

Brimont, L., Ezzine-de-Blas, D., Karsenty, A., \& Toulon, A. (2015). Achieving Conservation and Equity amidst Extreme Poverty and Climate Risk: The Makira REDD+ Project in Madagascar. Forests, 6(3), 748.

Brooks, T. M., Mittermeier, R. A., Fonseca, G. A. B. d., Gerlach, J., Hoffmann, M., Lamoreux, J. F., . . . Rodrigues, A. S. L. (2006). Global Biodiversity Conservation Priorities. Science, 313(5783), 58-61.

Brovkin, V., Boysen, L., Arora, V. K., Boisier, J. P., Cadule, P., Chini, L., .. Weiss, M. (2013). Effect of Anthropogenic Land-Use and Land-Cover Changes on Climate and Land 
Carbon Storage in CMIP5 Projections for the Twenty-First Century. Journal of Climate, 26(18), 6859-6881. doi:10.1175/jcli-d-12-00623.1

Brown, D. S., Brown, J. C., \& Brown, C. (2016). Land occupations and deforestation in the Brazilian Amazon. Land Use Policy, 54, 331-338. doi:https://doi.org/10.1016/j.landusepol.2016.02.003

Brown, G., \& Kyttä, M. (2018). Key issues and priorities in participatory mapping: Toward integration or increased specialization? Applied Geography, 95, 1-8. doi:https://doi.org/10.1016/j.apgeog.2018.04.002

Brown, M. L. (2009). Madagascar's Cyclone Vulnerability and the Global Vanilla Economy. In E. C. Jones \& A. D. Murphy (Eds.), The Political Economy of Hazards and Disasters (pp. 241-264). Plymouth: AltaMira Press.

Brownell, R. J. (2011). Fair Trade - The Future of Vanilla? In D. Havkin-Frenkel \& F. C. Belanger (Eds.), Handbook of Vanilla Science and Technology (pp. 107-116). Chichester, UK: Wiley-Blackwell.

Byerlee, D., Stevenson, J., \& Villoria, N. (2014). Does intensification slow crop land expansion or encourage deforestation? Global Food Security, 3(2), 92-98. doi:http://dx.doi.org/10.1016/j.gfs.2014.04.001

Casse, T., \& Milhøj, A. (2012). La gestion forestière communautaire dans le Sud-Ouest de Madagascar : une réussite sans profit économique ? Les Cahiers d'Outre-Mer, 258, 287-299.

Castella, J.-C., Lestrelin, G., Hett, C., Bourgoin, J., Fitriana, Y. R., Heinimann, A., \& Pfund, J.-L. (2013). Effects of Landscape Segregation on Livelihood Vulnerability: Moving From Extensive Shifting Cultivation to Rotational Agriculture and Natural Forests in Northern Laos. Human Ecology, 41(1), 63-76. doi:10.1007/s10745-012-9538-8

Ceddia, M. G., Bardsley, N. O., Gomez-y-Paloma, S., \& Sedlacek, S. (2014). Governance, agricultural intensification, and land sparing in tropical South America. Proceedings of the National Academy of Sciences. doi:10.1073/pnas.1317967111

Ceddia, M. G., \& Zepharovich, E. (2017). Jevons paradox and the loss of natural habitat in the Argentinean Chaco: The impact of the indigenous communities' land titling and the 
Forest Law in the province of Salta. Land Use Policy, 69, 608-617. doi:https://doi.org/10.1016/j.landusepol.2017.09.044

Congalton, R. G., \& Green, K. (2009). Assessing the accuracy of remotely sensed data : principles and practices (2nd ed.). Boca Raton, FL: Taylor \& Francis.

Cramb, R. A., Colfer, C. J. P., Dressler, W., Laungaramsri, P., Le, Q. T., Mulyoutami, E., . . . Wadley, R. L. (2009). Swidden Transformations and Rural Livelihoods in Southeast Asia. Human Ecology, 37(3), 323-346. doi:10.1007/s10745-009-9241-6

Curtis, P. G., Slay, C. M., Harris, N. L., Tyukavina, A., \& Hansen, M. C. (2018). Classifying drivers of global forest loss. Science, 361(6407), 1108-1111. doi:10.1126/science.aau3445

Danthu, P., Penot, E., Ranoarisoa, K. M., Rakotondravelo, J. C., Michel, I., Tiollier, M., .. . Jahiel, M. (2014). The clove tree of Madagascar: a success story with an unpredictable future. Bois et Forêts des Tropiques, 320(2), 83-96.

DeFries, R. S., Foley, J. A., \& Asner, G. P. (2004). Land-use choices: balancing human needs and ecosystem function. Frontiers in Ecology and the Environment, 2(5), 249-257. doi:10.1890/1540-9295(2004)002[0249:LCBHNA]2.0.CO;2

DeFries, R. S., Rudel, T., Uriarte, M., \& Hansen, M. (2010). Deforestation driven by urban population growth and agricultural trade in the twenty-first century. Nature Geoscience, 3, 178. doi:10.1038/ngeo756

https://www.nature.com/articles/ngeo756\#supplementary-information

Desbureaux, S., Kéré, E., \& Combes Motel, P. (2016). Impact Evaluation in a Landscape: Protected Natural Forests, Anthropized Forested Lands and Deforestation Leakages in Madagascar's Rainforests. Études et Documents, 13.

Eakin, H., DeFries, R., Kerr, S., Lambin, E. F., Liu, J., Marcotullio, P. J., . . Z Zimmerer, K. (2014). Significance of Telecoupling for Exploration of Land-Use Change. In K. C. Seto \& A. Reenberg (Eds.), Rethinking Global land Use in an Urban Era (pp. 141162). Cambridge, Massachusetts and London, England: The MIT Press.

Eklund, J., Blanchet, F. G., Nyman, J., Rocha, R., Virtanen, T., \& Cabeza, M. (2016). Contrasting spatial and temporal trends of protected area effectiveness in mitigating deforestation in Madagascar. Biological Conservation, 203, 290-297. doi:https://doi.org/10.1016/j.biocon.2016.09.033

Ewers, R. M., \& Rodrigues, A. S. L. (2008). Estimates of reserve effectiveness are confounded by leakage. Trends in Ecology \& Evolution, 23(3), 113-116. doi:https://doi.org/10.1016/j.tree.2007.11.008

FAO. (2018). Sustainable Intensification of Agriculture. Retrieved from http://www.fao.org/policy-support/policy-themes/sustainable-intensificationagriculture/en/

Ferraro, P. J., \& Hanauer, M. M. (2014). Quantifying causal mechanisms to determine how protected areas affect poverty through changes in ecosystem services and infrastructure. Proceedings of the National Academy of Sciences. doi:10.1073/pnas.1307712111

Fischer, J., Batáry, P., Bawa, K. S., Brussaard, L., Chappell, M. J., Clough, Y., . . . Von Wehrden, H. (2011). Conservation: Limits of Land Sparing. Science, 334(6056), 593593. doi:10.1126/science.334.6056.593-a

Foley, J. A., DeFries, R., Asner, G. P., Barford, C., Bonan, G., Carpenter, S. R., . . Snyder, P. K. (2005). Global Consequences of Land Use. Science, 309(5734), 570-574. doi:10.1126/science.1111772

Gardner, C. J., Nicoll, M. E., Birkinshaw, C., Harris, A., Lewis, R. E., Rakotomalala, D., \& Ratsifandrihamanana, A. N. (2018). The rapid expansion of Madagascar's protected 
area system. Biological Conservation, 220, 29. doi:https://doi.org/10.1016/j.biocon.2018.02.011

Gorenflo, L. J., Corson, C., Chomitz, K. M., Grady Harper, Honzák, M., \& Özler, B. (2011). Exploring the Association Between People and Deforestation in Madagascar. In R. P. Cincotta \& L. J. Gorenflo (Eds.), Human Population. Its Influences on Biological Diversity (pp. 197-221). Verlag, Berlin, Heidelberg: Springer.

Green, R. E., Cornell, S. J., Scharlemann, J. P. W., \& Balmford, A. (2005). Farming and the Fate of Wild Nature. Science, 307(5709), 550-555. doi:10.1126/science.1106049

Grogan, K., Birch-Thomsen, T., \& Lyimo, J. (2013). Transition of Shifting Cultivation and its Impact on People's Livelihoods in the Miombo Woodlands of Northern Zambia and South-Western Tanzania. Human Ecology, 41, 77-92.

Grünbühel, C. M., Singh, S. J., \& Fischer-Kowalski, M. (2007). The local base of transitions in developing countries. In M. Fischer-Kowalski \& H. Haberl (Eds.), Socioecological Transitions and Global Change. Trajectories of Social Metabolism and Land Use (pp. 139-178). Cheltenham, UK, and Northampton, USA: Edward Elgar Publishing.

Heinimann, A., Flint, C., Bernhard, R., \& Hett, C. (2017). Putting upland agriculture on the map: The TABI experience in Laos. In M. Crains (Ed.), Shifting Cultivation Policies: Balancing Environmental and Social Sustainability. Wallingford, United Kingdom: CABI.

Heinimann, A., Hett, C., Hurni, K., Messerli, P., Epprecht, M., Jørgensen, L., \& Breu, T. (2013). Socio-Economic Perspectives on Shifting Cultivation Landscapes in Northern Laos. Human Ecology, 41(51-62).

Heinimann, A., Mertz, O., Frolking, S., Egelund Christensen, A., Hurni, K., Sedano, F., . . . Hurtt, G. (2017). A global view of shifting cultivation: Recent, current, and future extent. PLoS ONE, 12(9), e0184479. doi:10.1371/journal.pone.0184479

Hill, R., Miller, C., Newell, B., Dunlop, M., \& Gordon, I. J. (2015). Why biodiversity declines as protected areas increase: the effect of the power of governance regimes on sustainable landscapes. Sustainability Science, 10(2), 357-369. doi:10.1007/s11625015-0288-6

Hodgson, J. A. (2016). A Genomic Investigation of the Malagasy Confirms the HighlandCoastal Divide, and the Lack of Middle Eastern Gene Flow. In G. Campbell (Ed.), Early Exchange between Africa and the Wider Indian Ocean World (pp. 231-254). Cham: Springer International Publishing.

Holmes, C. (2007). Linking Livelihoods, Land Stewardship, and Resource Conservation in the Antongil Bay Landscape, Madagascar. In K. H. Redford \& E. Fearn (Eds.), Protected areas and human livelihoods. WCS Working Paper. 32. Bronx, New York: Wildlife Conservation Society.

Houghton, R. A., House, J. I., Pongratz, J., van der Werf, G. R., DeFries, R. S., Hansen, M. C., . . Ramankutty, N. (2012). Carbon emissions from land use and land-cover change. Biogeosciences, 9(12), 5125-5142. doi:10.5194/bg-9-5125-2012

Hufty, M., \& Muttenzer, F. (2002). Devoted Friends: The Implementation of the Convention on Biological Diversity in Madagascar. In P. L. Prestre (Ed.), Governing Global Biodiversity (pp. pp. 279-309). London: Ashgate.

Janssen, T. A. J., Ametsitsi, G. K. D., Collins, M., Adu-Bredu, S., Oliveras, I., Mitchard, E. T. A., \& Veenendaal, E. M. (2018). Extending the baseline of tropical dry forest loss in Ghana (1984-2015) reveals drivers of major deforestation inside a protected area. Biological Conservation, 218, 163-172. doi:https://doi.org/10.1016/j.biocon.2017.12.004

Jantz, S. M., Barker, B., Brooks, T. M., Chini, L. P., Huang, Q., Moore, R. M., . . Hurtt, G. C. (2015). Future habitat loss and extinctions driven by land-use change in biodiversity 
hotspots under four scenarios of climate-change mitigation. Conservation Biology, 29(4), 1122-1131. doi:10.1111/cobi.12549

Jepsen, M. R., Kuemmerle, T., Müller, D., Erb, K., Verburg, P. H., Haberl, H., . . . Reenberg, A. (2015). Transitions in European land-management regimes between 1800 and 2010. Land Use Policy, 49, 53-64. doi:https://doi.org/10.1016/j.landusepol.2015.07.003

Jevons, W. S. (1865). The Coal Question: An Enquiry Concerning the Progress of the Nation, and the Probable Exhaustion of Our Coal-mines. London and Cambridge: MacMillan and Co. .

Jones, J. P. G., Andriahajaina, F. B., Ranambinintsoa, E. H., Hockley, N. J., \& Ravoahangimalala, O. (2006). The economic importance of freshwater crayfish harvesting in Madagascar and the potential of community-based conservation to improve management. Oryx, 40(2), 168-175. doi:10.1017/S0030605306000500

Käyhkö, N., Fagerholm, N., \& Mzee, A. J. (2015). Local farmers’ place-based forest benefits and government interventions behind land and forest cover transitions in Zanzibar, Tanzania. Journal of Land Use Science, 10(2), 150-173. doi:10.1080/1747423X.2013.858784

Keane, A., Ramarolahy, A. A., Jones, J. P. G., \& Milner-Gulland, E. J. (2011). Evidence for the effects of environmental engagement and education on knowledge of wildlife laws in Madagascar. Conservation Letters, 4(1), 55-63. doi:doi:10.1111/j.1755263X.2010.00144.x

Keller, E. (2009). Who are "they"? Local understandings of NGO and state power in Masoala, Madagascar. Tsantsa, 14, 76-85.

Keller, E. (2015). Beyond the Lens of Conservation. Malagasy and Swiss Imaginations of One Another. New York and Oxford: Berghahn Books.

Kilawe, C. J., Mertz, O., Silayo, D. S. A., Birch-Thomsen, T., \& Maliondo, S. M. (2018). Transformation of shifting cultivation: Extent, driving forces and impacts on livelihoods in Tanzania. Applied Geography, 94, 84-94. doi:https://doi.org/10.1016/j.apgeog.2018.03.002

Kim Chi, V., Rompaey, A. V., Govers, G., Vanacker, V., Schmook, B., \& Hieu, N. (2013). Land Transitions in Northwest Vietnam: An Integrated Analysis of Biophysical and Socio-Cultural Factors. Human Ecology, 41(37-50).

Kim, D.-H., Sexton, J. O., \& Townshend, J. R. (2015). Accelerated deforestation in the humid tropics from the 1990s to the 2000s. Geophysical Research Letters, 42(9), 3495-3501. doi:doi:10.1002/2014GL062777

Knight, D. W., Mendezona Allegretti, A., \& Vaske, J. J. (2015). Information disseminationdiffusion and marine protected area approval in the Philippines. Ocean \& Coastal Management, 113, 38-46. doi:https://doi.org/10.1016/j.ocecoaman.2015.05.016

Kremen, C., Razafimahatratra, V., Guillery, R. P., Rakotomalala, J., Weiss, A., \& Ratsisompatrarivo, J.-S. (1999). Designing the Masoala National Park in Madagascar 
Based on Biological and Socioeconomic Data. Conservation Biology, 13(5), 10551068. doi:10.1046/j.1523-1739.1999.98374.x

Kull, C. A. (1996). The Evolution of Conservation Efforts in Madagascar. international Environmental Affairs, 8(1), 50-86.

Kull, C. A. (2004). Isle of Fire. The Political Ecology of Landscape Burning in Madagascar. Chicago and London: The University of Chicago Press.

Kull, C. A. (2014). The roots, persistence, and character of Madagascar's conservation boom. In I. R. Scales (Ed.), Conservation and Environmental Management in Madagascar (pp. 146-171). Abingdon and New York: Routledge.

Kull, C. A. (2017). Forest transitions: a new conceptual scheme. Geogr. Helv., 72(4), 465-474. doi:10.5194/gh-72-465-2017

Kull, C. A., Ibrahim, C. K., \& Meredith, T. C. (2007). Tropical Forest Transitions and Globalization: Neo-Liberalism, Migration, Tourism, and International Conservation Agendas. Society \& Natural Resources: An International Journal, 20(8), 723-737.

Kuusela, O.-P., \& Amacher, G. S. (2016). Changing Political Regimes and Tropical Deforestation. Environmental and Resource Economics, 64(3), 445-463. doi:10.1007/s10640-015-9880-6

Lambin, E. F., Geist, H. J., \& Lepers, E. (2003). Dynamics of Land-Use and Land-Cover Change in Tropical Regions. Annual Review of Environment and Resources, 28, 205241.

Lambin, E. F., \& Meyfroidt, P. (2011). Global land use change, economic globalization, and the looming land scarcity. Proceedings of the National Academy of Sciences of the United States of America, 108(9), 3465-3472. doi:10.1073/pnas.1100480108

Laney, R., \& Turner, B. L. (2015). The Persistence of Self-Provisioning Among Smallholder Farmers in Northeast Madagascar. Human Ecology, 43(6), 811-826. doi:10.1007/s10745-015-9791-8

Laney, R. M. (2002). Disaggregating Induced Intensification for Land-Change Analysis: A Case Study from Madagascar. Annals of the Association of American Geographers, 92(4), 702-726.

Laurance, W. F., Sayer, J., \& Cassman, K. G. (2014). Agricultural expansion and its impacts on tropical nature. Trends in Ecology \& Evolution, 29(2), 107-116. doi:https://doi.org/10.1016/j.tree.2013.12.001

Lim, C. L., Prescott, G. W., Alban, J. D. T., Ziegler, A. D., \& Webb, E. L. (2017). Untangling the proximate causes and underlying drivers of deforestation and forest degradation in Myanmar. Conservation Biology, 31(6), 1362-1372. doi:doi:10.1111/cobi.12984

Liu, J., Hull, V., Batistella, M., DeFries, R., Dietz, T., Fu, F., . . . Zhu, C. (2013). Framing Sustainability in a Telecoupled World. Ecology and Society, 18(2). doi:10.5751/ES05873-180226

Llopis, J. C. (2018). Down by the Riverside: Cyclone-Driven Floods and the Expansion of Swidden Agriculture in Southwestern Madagascar. In J. Abbink (Ed.), The Environmental Crunch in Africa (pp. 241-268). Cham: Palgrave Macmillan.

Lui, G. V., \& Coomes, D. A. (2016). Tropical nature reserves are losing their buffer zones, but leakage is not to blame. Environmental Research, 147, 580-589. doi:https://doi.org/10.1016/j.envres.2015.11.008

Marcus, R. R. (2001). Seeing the Forest for the Trees: Integrated Conservation and Development Projects and Local Perceptions of Conservation in Madagascar. Human Ecology, 29(4), 381-397. doi:10.1023/A:1013189720278

McConnell, W., Viña, A., Kull, C., \& Batko, C. (2015). Forest Transition in Madagascar's Highlands: Initial Evidence and Implications. Land, 4(4), 1155. 
McDermott, G. R., Meng, K. C., McDonald, G. G., \& Costello, C. J. (2018). The blue paradox: Preemptive overfishing in marine reserves. Proceedings of the National Academy of Sciences. doi:10.1073/pnas.1802862115

Mertz, O., Padoch, C., Fox, J., Cramb, R. A., Leisz, S. J., Lam, N. T., \& Vien, T. D. (2009). Swidden Change in Southeast Asia: Understanding Causes and Consequences. Human Ecology, 37(3), 259-264.

Messerli, P. (2006). Exploring innovative strategies for livelihoods in a slash-and-burn context in Madagascar: Experiencing the role of human geography in sustainability-oriented research. Geographica Helvetica, 61(4), 266-274.

Meyers, D. (2001). Makira Forest Project, Madagascar. Report to the Ministry of Environment: MEF - IRG/PAGE - USAID.

Meyfroidt, P., Kimberly, M. C., Matthew, E. F., Victor, H. G.-V., Marcia, N. M., Lisa, M. C., . . . Valentina, R. (2014). Multiple pathways of commodity crop expansion in tropical forest landscapes. Environmental Research Letters, 9(7), 074012.

Meyfroidt, P., \& Lambin, E. F. (2011). Global Forest Transition: Prospects for an End to Deforestation. Annual Review of Environment and Resources, 36(1), 343-371. doi:10.1146/annurev-environ-090710-143732

Meyfroidt, P., Lambin, E. F., Erb, K.-H., \& Hertel, T. W. (2013). Globalization of land use: distant drivers of land change and geographic displacement of land use. Current Opinion in Environmental Sustainability, 5(5), 438-444. doi:https://doi.org/10.1016/j.cosust.2013.04.003

Meyfroidt, P., Roy Chowdhury, R., de Bremond, A., Ellis, E. C., Erb, K. H., Filatova, T., .. . Verburg, P. H. (2018). Middle-range theories of land system change. Global Environmental Change, 53, 53. doi:https://doi.org/10.1016/j.gloenvcha.2018.08.006

Middleton, K. (2013). Land Rights and Alien Plants in Dryland Madagascar. In S. Evers, G. Campbell, \& M. Lambek (Eds.), Contest for Land in Madagascar

(pp. 141-170). Leiden: Brill.

Minten, B., Meral, P., Randrianarison, L., \& Swinnen, J. F. M. (2006). Trade Liberalization, Rural Poverty And The Environment: The Case Of Madagascar. Antananarivo: WWF Madagascar.

Mittermeier, R. A., Turner, W. R., Larsen, F. W., Brooks, T. M., \& Gascon, C. (2011). Global Biodiversity Conservation: The Critical Role of Hotspots. In F. E. Zachos \& J. C. Habel (Eds.), Biodiversity Hotspots: Distribution and Protection of Conservation Priority Areas (pp. 3-22). Berlin, Heidelberg: Springer Berlin Heidelberg.

MNP. (2015). Parc National Masoala - Nosy Mangabe. Retrieved from http://parcsmadagascar.com/aire-prot\%C3\%A9g\%C3\%A9e/parc-national-masoala-nosymangabe

MNP. (2017). GIS data for Masoala National Park: Madagascar National Parks.

Müller, D., Sun, Z., Vongvisouk, T., Pflugmacher, D., Xu, J., \& Mertz, O. (2014). Regime shifts limit the predictability of land-system change. Global Environmental Change, 28, 75-83. doi:https://doi.org/10.1016/j.gloenvcha.2014.06.003

Mustard, J. F., Defries, R. S., Fisher, T., \& Moran, E. (2004). Land-Use and Land-Cover Change Pathways and Impacts. In G. Gutman, A. C. Janetos, C. O. Justice, E. F. Moran, J. F. Mustard, R. R. Rindfuss, D. Skole, B. L. Turner, \& M. A. Cochrane (Eds.), Land Change Science: Observing, Monitoring and Understanding Trajectories of Change on the Earth's Surface (pp. 421-439). Dordrecht: Springer Netherlands.

Myers, N., Mittermeier, R. A., Mittermeier, C. G., Fonseca, G. A. B. d., \& Kent, J. (2000). Biodiversity hotspots for conservation priorities. Nature, 403(6772), 853-858.

Nackoney, J., Rybock, D., Dupain, J., \& Facheux, C. (2013). Coupling participatory mapping and GIS to inform village-level agricultural zoning in the Democratic Republic of the 
Congo. Landscape and Urban Planning, 110, 164-174. doi:http://dx.doi.org/10.1016/j.landurbplan.2012.11.004

Neudert, R., Olschofsky, K., Kübler, D., Prill, L., Köhl, M., \& Wätzold, F. (2018). Opportunity costs of conserving a dry tropical forest under REDD+: The case of the spiny dry forest in southwestern Madagascar. Forest Policy and Economics, 95, 102-114. doi:https://doi.org/10.1016/j.forpol.2018.07.013

Niewöhner, J., Bruns, A., Haberl, H., Hostert, P., Krueger, T., Lauk, C., . . . Nielsen, J. Ø. (2016). Land Use Competition: Ecological, Economic and Social Perspectives. In J. Niewöhner, A. Bruns, P. Hostert, T. Krueger, J. Ø. Nielsen, H. Haberl, C. Lauk, J. Lutz, \& D. Müller (Eds.), Land Use Competition: Ecological, Economic and Social Perspectives (pp. 1-17). Cham: Springer International Publishing.

Nolte, C., Gobbi, B., le Polain de Waroux, Y., Piquer-Rodríguez, M., Butsic, V., \& Lambin, E. F. (2018). Challenges in Attributing Avoided Deforestation to Policies and Actors: Lessons From Provincial Forest Zoning in the Argentine Dry Chaco. Ecological Economics, 150, 346-352. doi:https://doi.org/10.1016/j.ecolecon.2018.03.010

Oestreicher, J. S., Benessaiah, K., Ruiz-Jaen, M. C., Sloan, S., Turner, K., Pelletier, J., . . . Potvin, C. (2009). Avoiding deforestation in Panamanian protected areas: An analysis of protection effectiveness and implications for reducing emissions from deforestation and forest degradation. Global Environmental Change, 19(2), 279-291. doi:https://doi.org/10.1016/j.gloenvcha.2009.01.003

Oliveira, P. J. C., Asner, G. P., Knapp, D. E., Almeyda, A., Galván-Gildemeister, R., Keene, S., . . . Smith, R. C. (2007). Land-Use Allocation Protects the Peruvian Amazon. Science, 317(5842), 1233-1236. doi:10.1126/science.1146324

ONE, DGF, FTM, MNP, \& CI. (2013). Evolution de la Couverture de forêts naturelles à Madagascar 2005-2010. Antananarivo.

Ormsby, A., \& Kaplin, B. A. (2005). A framework for understanding community resident perceptions of Masoala National Park, Madagascar. Environmental Conservation, 32(02), 156-164. doi:doi:10.1017/S0376892905002146

Osterhoudt, S. (2016). Written with seed: the political ecology of memory in Madagascar. Journal of Political Ecology, 23, 263-278.

Phelps, J., Carrasco, L. R., Webb, E. L., Koh, L. P., \& Pascual, U. (2013). Agricultural intensification escalates future conservation costs. Proceedings of the National Academy of Sciences, 110(19), 7601-7606. doi:10.1073/pnas.1220070110

Pollini, J. (2012). Understanding agricultural intensification on a forest frontier in Madagascar: elements of a Malthusian/Boserupian synthesis. In J. Sumberg \& J. Thompson (Eds.), Contested Agronomy: the Politics of Agricultural Research in a Changing World (pp. 116-130). Oxford, UK: Earthscan.

Pollini, J., Hockley, N., Muttenzer, F. D., \& Ramamonjisoa, B. S. (2014). The transfer of natural resource management rights to local communities. In I. R. Scales (Ed.), Conservation and Environmental Management in Madagascar (pp. 173-192). Abingdon and New York: Routledge.

Poudyal, M., Ramamonjisoa, B. S., Hockley, N., Rakotonarivo, O. S., Gibbons, J. M., Mandimbiniaina, R., . . . Jones, J. P. G. (2016). Can REDD+ social safeguards reach 
the 'right' people? Lessons from Madagascar. Global Environmental Change, 37, 3142. doi:http://dx.doi.org/10.1016/j.gloenvcha.2016.01.004

Raik, D. B., \& Decker, D. J. (2007). A Multisector Framework for Assessing CommunityBased Forest Management: Lessons from Madagascar. Ecology and Society, 1(14).

Ramankutty, N., \& Coomes, O. T. (2016). Land-use regime shifts: an analytical framework and agenda for future land-use research. Ecology and Society, 21(2). doi:10.5751/ES08370-210201

Randriamalala, H., \& Liu, Z. (2010). Rosewood of Madagascar: Between democracy and conservation. Madagascar Conservation \& Development, 5(1), 11-22.

Rasmussen, L. V., Coolsaet, B., Martin, A., Mertz, O., Pascual, U., Corbera, E., . . Ryan, C. M. (2018). Social-ecological outcomes of agricultural intensification. Nature Sustainability, 1(6), 275-282. doi:10.1038/s41893-018-0070-8

Ratsimbazafy, C. L., Harada, K., \& Yamamura, M. (2012). Forest resources use, attitude, and perception of local residents towards community based forest management: Case of the Makira Reducing Emissions from Deforestation and Forest Degradation (REDD) Project, Madagascar. Journal of Ecology and the Natural Environment, 4(13), 321-332.

Rockström, J., Williams, J., Daily, G., Noble, A., Matthews, N., Gordon, L., . . . Smith, J. (2017). Sustainable intensification of agriculture for human prosperity and global sustainability. Ambio, 46(1), 4-17. doi:10.1007/s13280-016-0793-6

Scales, I. R. (2011). Farming at the Forest Frontier: Land Use and Landscape Change in Western Madagascar, 1896-2005. Environment and History, 17, 499-524.

Schuurman, D., \& Lowry II, P. P. (2009). The Madagascar rosewood massacre. Madagascar Conservation \& Development, 4(2), 98-102.

Sloan, S., Jenkins, C. N., Joppa, L. N., Gaveau, D. L. A., \& Laurance, W. F. (2014). Remaining natural vegetation in the global biodiversity hotspots. Biological Conservation, 177, 12-24. doi:https://doi.org/10.1016/j.biocon.2014.05.027

Snyder, P. K., Delire, C., \& Foley, J. A. (2004). Evaluating the influence of different vegetation biomes on the global climate. Climate Dynamics, 23(3), 279-302. doi:10.1007/s00382004-0430-0

Spracklen, B. D., Kalamandeen, M., Galbraith, D., Gloor, E., \& Spracklen, D. V. (2015). A Global Analysis of Deforestation in Moist Tropical Forest Protected Areas. PLoS ONE, 10(12), e0143886. doi:10.1371/journal.pone.0143886

Steffen, W., Broadgate, W., Deutsch, L., Gaffney, O., \& Ludwig, C. (2015). The trajectory of the Anthropocene: The Great Acceleration. The Anthropocene Review, 2(1), 81-98. doi:10.1177/2053019614564785

Sterling, S. M., Ducharne, A., \& Polcher, J. (2012). The impact of global land-cover change on the terrestrial water cycle. Nature Climate Change, 3, 385. doi:10.1038/nclimate1690

https://www.nature.com/articles/nclimate1690\#supplementary-information

Tilman, D., Balzer, C., Hill, J., \& Befort, B. L. (2011). Global food demand and the sustainable intensification of agriculture. Proceedings of the National Academy of Sciences, 108(50), 20260-20264. doi:10.1073/pnas.1116437108

Trimble. (2013). eCognition Developer 8. Munich, Germany: Trimble Germany GmbH.

Urech, Z. L., Zaehringer, J. G., Rickenbach, O., Sorg, J.-P., \& Felber, H. R. (2015). Understanding deforestation and forest fragmentation from a livelihood perspective. Madagascar Conservation \& Development, 10(2), 67-76.

Vågen, T.-G. (2006). Remote sensing of complex land use change trajectories-a case study from the highlands of Madagascar. Agriculture, Ecosystems and Environment, 115, 219-228.

van Vliet, N., Mertz, O., Heinimann, A., Langanke, T., Pascual, U., Schmook, B., . . Ziegler, A. D. (2012). Trends, drivers and impacts of changes in swidden cultivation in tropical 
forest-agriculture frontiers: A global assessment. Global Environmental Change, 22, 418-429.

Verburg, P. H., Crossman, N., Ellis, E. C., Heinimann, A., Hostert, P., Mertz, O., . . Zhen, L. (2015). Land system science and sustainable development of the earth system: A global $\begin{array}{lll}\text { land project } & \text { perspective. }\end{array}$ doi:http://dx.doi.org/10.1016/j.ancene.2015.09.004

Vongvisouk, T., Broegaard, R. B., Mertz, O., \& Thongmanivong, S. (2016). Rush for cash crops and forest protection: Neither land sparing nor land sharing. Land Use Policy, 55, 182-192. doi:https://doi.org/10.1016/j.landusepol.2016.04.001

Waeber, P. O., Schuurman, D., \& Wilmé, L. (2018). Madagascar’s rosewood (Dalbergia spp.) stocks as a political challenge. PeerJ Preprints, 6(e27062v1).

Waeber, P. O., Wilmé, L., Mercier, J.-R., Camara, C., \& Lowry II, P. P. (2016). How Effective Have Thirty Years of Internationally Driven Conservation and Development Efforts Been in Madagascar? PLoS ONE, 11(8), e0161115. doi:10.1371/journal.pone.0161115

Waeber, P. O., Wilmé, L., Ramamonjisoa, B., Garcia, C., Rakotomalala, D., Z.H. Rabemananjara, ... Sorg, J.-P. (2015). Dry forests in Madagascar: neglected and under pressure. International Forestry Review, 17(S2), 127-148.

Watson, J. E. M., Dudley, N., Segan, D. B., \& Hockings, M. (2014). The performance and potential of protected areas. Nature, 515, 67. doi:10.1038/nature13947

https://www.nature.com/articles/nature13947\#supplementary-information

WCS. (2018). Makira Natural Park. Retrieved from https://madagascar.wcs.org/WildPlaces/Makira-Natural-Park.aspx

Zaehringer, J., Eckert, S., \& Messerli, P. (2015). Revealing Regional Deforestation Dynamics in North-Eastern Madagascar-Insights from Multi-Temporal Land Cover Change Analysis. Land, 4(2), 454.

Zaehringer, J. G., Llopis, J. C., Latthachack, P., Thein, T. T., \& Heinimann, A. (2018). A novel participatory and remote sensing-based approach to mapping annual land use change on forest frontiers in Laos, Myanmar, and Madagascar. Journal Of Land Use Science, 1-16.

Zaehringer, J. G., Hett, C., Ramamonjisoa, B., \& Messerli, P. (2016). Beyond deforestation monitoring in conservation hotspots: Analysing landscape mosaic dynamics in northeastern Madagascar. Applied Geography, 68, 9-19. doi:http://dx.doi.org/10.1016/j.apgeog.2015.12.009

Zhu, A. (2018). Hot money, cold beer: Navigating the vanilla and rosewood export economies in northeastern Madagascar. American Ethnologist, 45(2), 253-267. doi:doi:10.1111/amet.12636

Zinner, D., Wygoda, C., Razafimanantsoa, L., Rasoloarison, R., Andrianandrasana, H., Ganzhorn, J. U., \& Torkler, F. (2014). Analysis of deforestation patterns in the central 
Menabe, Madagascar, between 1973 and 2010. Regional Environmental Change, 14(1), 157-166. doi:10.1007/s10113-013-0475-x 


\section{SI.1. Expanded explanation of the methodological approach}

For this study, we adapted the methodology developed by AAAA (2018) to reconstruct land use transitions in the humid tropics. The overarching idea of the approach (Figure 2 in the paper) is to combine object-based spatial delineation of the plots in our study landscapes based on very highresolution (VHR, $0.5 \mathrm{~m} /$ pixel) remote sensing imagery with participatory methods supported by ancillary data (Table 2 in the paper) to identify current land use and land use trajectories in each plot from 1990 to 2017. In order to gain explanatory insights on the temporally explicit factors affecting local land use decision-making, and thus the land use transitions in the study landscapes, we gathered qualitative evidence through interviews with key informants and participatory workshops. To complete these tasks, we conducted participatory fieldwork in April 2016, from October to December 2016, from August to November 2017, and in February 2019.

\section{Rationale for employing a participatory approach to complement remote sensing}

Remote sensing approaches are among the main tools the scientific community and conservation and development practitioners have to monitor land use and land cover (LULC) dynamics in a timely way. Remote sensing has witnessed significant developments in recent years, such as the advent of object-based classification methods, or the availability of everincreasing spatial, spectral, and temporal resolution satellite imagery. However, its applicability in the case of complex mosaic landscapes in the humid tropics is hampered by the cloud cover prevailing over these regions for most of the year, which limits the availability of temporally dense optical remote sensing data. Additionally, this challenge is further compounded by the subtle spectral and textural differences between some of the land uses commonly present in these landscapes, shifting cultivation and agroforestry systems, which impede accurate land use classification (Mertz et al., 2012). To date, a lack of continuous temporal and high enough spatial resolution data have prevented monitoring of the highly dynamic land use change processes triggered by cash crop booms in these forest frontier contexts, or timely analysis of LULC change dynamics before and after PA establishment. Participatory mapping approaches are increasingly employed to gather stakeholder-relevant spatial information not available through remote sensing technologies (Brown \& Kyttä, 2018). The strength of this avenue for co-producing spatially explicit knowledge has already been shown in ecosystem services mapping (Brown \& Fagerholm, 2015; Klain \& Chan, 2012), and landscape planning (Heinimann, Flint, Bernhard, \& Hett, 2017; Nackoney, Rybock, Dupain, \& Facheux, 2013), 
whereas its potential to complement remote sensing data to monitor land use change dynamics in forest frontier contexts remains largely untapped.

\section{SI 1.1 - Obtaining contextual landscape knowledge and developing a land use classification scheme (Step 1)}

To obtain general information about the villages' settlement history, predominant land uses, and overall trajectories of change, as well as complementary information about the landscape, we conducted interviews with elders, farmers, and local authorities. We also undertook preliminary field walks with local land users to collect a first series of GPS points for all land uses in each study area, which subsequently helped to outline the land use classification scheme (Table 3 in the paper). We then conducted preliminary workshops with land users to elicit the major land use trajectories and drivers of land use change in the villages, which constituted the continuous trends and discrete events we explore in this study. The workshops also resulted in the classification scheme presented in table 3, which broadly aligns with how land use classes are commonly defined in this type of landscape in the region (Arimalala et al., 2018; Michels et al., 2011), and which was employed in the following mapping steps. To gain insights into the history of the PAs and the evolution of the different natural resource management regimes in our study landscapes, we also conducted interviews with PA managers, forest ministry officials, and administrative authorities in the national capital Antananarivo and in the capital of the district were our study landscapes are located, Maroantsetra.

\section{SI 1.2 - Object-based segmentation and delineation of spatial units for land use change assessment (Step 2)}

The objective of the next step was to establish the spatially explicit structure of the plots in our study landscapes, into which the participatory land use change information would be fed. To this end, we delineated the geometry of the spatial units of land use classification in our study landscapes - i.e. the agricultural plots - based on the most recent VHR multispectral satellite imagery available, acquired by the Pleiades satellite in 2016 and 2017 (table 2). Using this imagery, we systematically tested the 'multiresolution segmentation' algorithm available in eCognition Developer software (Trimble, 2013) with different parameters, until we obtained 
the most appropriate combination to represent each of the land uses we aimed at identifying. The most suitable combination was the following: scale: 48 ; image layers weight: $1,1,1$ (RGB), and 1.4 (NIR); shape: 0.82; and compactness: 0.85. We further refined the resulting segmentation by merging and splitting the polygons. The output of this step was the plot-level geometry for both study landscapes, which constituted the structure in which we would input the participatory land use change information collected in the next steps (SI 3). It is worth mentioning that agricultural plots in this study were defined solely on the basis of land use and its change dynamics, irrespective of the tenure situation. To account for changes in the extent of different land uses in each plot throughout the study period, we further refined the plot-level geometry based on the spatially explicit information collected during the field walks, as explained below.

\section{SI 1.3 - Participatory land use change workshops (Step 3)}

The next step had a three-fold objective. First, to delineate the study landscape boundaries; second, to obtain the spatially explicit context knowledge needed to plan the field walks; and third, to elicit the trajectories of land use change for the different sections of the landscape. To this end, we conducted a participatory land use change mapping workshop in each study site. The workshop in Beanana lasted a full day and involved eight participants, whereas the one in Fizono lasted half a day and counted five participants. Participants were sought among local land users holding extensive knowledge about the landscape dynamics over the last 30 years; accordingly, participants contributing to this study were aged 45 years or older at the time when fieldwork was conducted. While this sampling strategy might not be representative of the diversity within the population in our study villages, we consider it the most appropriate strategy to achieve our goal, namely to obtain the most accurate possible information on land use change in these landscapes, which we assume to be relatively objective information. Further explanation of this sampling strategy can be found in AAAA (2018).

For the workshops, we printed the most recent VHR satellite imagery in A0 format at a scale of 1:10,000. The printout was then covered with transparent plastic sheets on which the participants were asked to draw and write the information required. First, and as commonly done in this type of exercise (Bourgoin, Castella, Pullar, Lestrelin, \& Bouahom, 2012), participants were asked to outline the exact land boundaries of the village, and to name the main geographical features of the landscape, including rivers, valleys, mountain ridges, and 
sections of the village landscape. Second, we asked participants to identify the current land uses in the satellite imagery, to elaborate on the spatially explicit land use trajectories (e.g. current and previous land uses and date of change) at the level of landscape sections (e.g. the slope of a valley, ridge of a hill, etc.), and to the extent possible at plot level. We registered all the spatially explicit information on the transparent plastic sheets covering the recent satellite imagery, and to the degree possible, transferred it directly to the plot-level geometry, which we also printed for the workshop in transparent A3 sheets.

In order to support the exercise and triangulate the information offered by participants, we employed ancillary remote sensing and Landsat-based GIS data printed on A3 sheets at a scale of 1:10,000 (Table 2 in the paper and SI. 2). Concretely, we relied on all available and suitable past VHR satellite imagery covering our study landscapes, specifically for the years 2006, 2011, 2012, and 2014, as well as medium-resolution imagery from Landsat and Sentinel satellites spanning the entire study period. The Landsat-based GIS data included regional land cover data for 1995, 2005, and 2011 (Zaehringer, Eckert, \& Messerli, 2015); national-level forest cover evolution data for 1990, 2000, 2005, and 2010 (MEEF et al., 2007; ONE, DGF, FTM, MNP, \& CI, 2013); and Global Forest Change (GFC) data for 2000-2017 (Hansen et al., 2013). Additionally, we employed the 12-m-resolution TanDEM-X digital elevation model (DEM) provided by DLR to support the localization and identification of plots and geographical features. The output of the workshops included an understanding of the land use trajectories for all sections of the study landscapes, including the most recent plot-level land use and change information for a substantial portion of the landscapes, and the boundaries of the study landscapes. Regarding the landscape boundaries, we further triangulated and refined them with resort to the following data. We first drew on the DEM provided by DLR to delimit the watersheds of the different study landscapes, which we related to several areas of the study landscapes where mountain ridges and water courses coincided with what local land users considered to be the boundaries of the study villages' area. Second, we contrasted these boundaries with the administrative GIS data at the municipality level (BNGRC \& OCHA, 2017), and discussed some incoherences between these administrative data and the local understanding of the landscape boundaries with the participants in our study. Finally, we further checked the exact location of the study landscape boundaries thus generated during the 
field walks in the following step.

\section{SI 1.4 - Obtaining plot-level information about land use trajectories (Step 4)}

The main purpose of the next step was to collect continuous information on the trajectories of land use change at plot level, for the plots on which we had not succeeded in compiling information during the participatory workshops. To this end, we conducted 25 field walks in the two villages (table 4), for which we required the assistance of one or two local land users knowledgeable about the different sections of the landscape covered in each walk. During the walks, we asked participants to identify the current and previous land uses in each plot, and the date on which one land use changed into another, particularly in the last 30 years. Discussions during the walks were supported with the current VHR imagery, ancillary data, and the plot-level geometry printed on A3 sheets at a scale of 1:10,000, including a metric grid to accurately localise the plots. During the walks, two main approaches were employed to capture the spatially explicit information provided by the local land users. First, we collected 2,107 GPS points with a GPS device (Garmin (c) xtrex x20). And second, we systematically took geolocalized pictures with photographic cameras equipped with a built-in GPS receiver and large optical zoom (Nikon Coolpix S9900 and Sony DCS HV400X). The goal of this step was to obtain land use change information for areas within our study landscapes that were not easy to reach physically. We specifically sought mountain ridges and other spots with panoramic views over the landscape to take pictures of, and discuss, the landscape. The direction of the pictures was registered with the camera's compass as well as an analogue compass, and to increase accuracy when identifying the plots, we collected pictures of the same plot from different positions in the landscape when possible. We obtained a total of 8,280 pictures (table 2) through this methodology, which were then processed and fed into our land use mapping workflow as explained below.

Finally, for areas of the landscapes that were not possible to cover, either with the GPS data collection procedure or with the geolocalized pictures, we resorted to the following approach. We conducted a visual interpretation on the printed satellite imagery with the aid of the local land user accompanying the research team, with the information of the already identified plots and further supported by the ancillary data available. In order to speed up data collection during the field walks, all data were registered with a voice recorder and later processed in Excel (Microsoft 2016), and, when possible, we transferred the information directly to the printed plot-level geometry. 


\section{SI 1.5 - Importing participatory land use change information into the plot-level geometry (Step}

5)

In the final step of our workflow we aimed to feed the continuous participatory land use change information into the plot-level geometry, and to refine the plot structure to account for changes in the extent of different land uses within plots throughout the study period. To do so, we exported the geometry generated during the object-based segmentation into ArcGIS (ESRI, 2017) in a shapefile format. In this software, we first fed the land use change information attached to the GPS points obtained through the participatory field walks into the plot-level geometry. Second, we conducted the same procedure with the land use change information linked to the geolocalized pictures, relying on the open access software GeoSetter (Schmidt, 2018), and the 3D landscape view of Google Earth. Finally, we assigned the data generated during discussions with local land users to classify the plots not reached physically or visually during the field walks. Throughout this process in the GIS software, we further divided the plots to account for the changing extent of different land uses in each plot. If, for example, we had information showing that half of a plot which at the most recent date appeared as entirely cultivated under an agroforesty system was converted from shifting cultivation into agroforest in 2010, we would divide the plot and assign that section of the plot the land use of shifting cultivation before 2010. The final output of this step was a plot-level land use map for each of the 28 years covered in our study period in the two study landscapes (Figure 3 in the paper).

A further explanation is required for reading Figure 6 in the paper, which shows the year-toyear from-to land use changes in our two study landscapes. In this study, we understand the 'year-toyear' change as the change in land use in a given plot from one year to the next. For example, the land use change date of a plot that was shifting cultivation in 2008 and open agroforest in 2009 would fall within the '2008-2009' tick of figure 6. The same logic applies to the conversion of forest into shifting cultivation; a plot which, for example, was forest in 2008 and shifting cultivation in 2009 would fall within our '2008-2009’ tick, even if it was effectively cleared, let us say, in December 2009.

\section{SI 1.6 - Land use classification scheme}

A further note on the land use classification scheme (Table 3) is required. In the shifting cultivation system, local farmers differentiate fallow stages according to land cover. They use land cover as an indicator of fallow length and cultivation cycle, and thus of plot fertility, in a way that is much more nuanced than the simplified land use classification scheme we present here. For the most recent date (2017), we were able to distinguish and classify up to four different shifting cultivation stages, based on land cover and dominating species, along the typology of other studies conducted in eastern Madagascar (e.g. Styger, Rakotondramasy, Pfeffer, Fernandes, \& Bates, 2007). However, it was not possible to complete such a disaggregated classification for the past, mainly because it was impossible to obtain consistent information for each year of cultivation of any given plot in the last 
three decades. This forced us to aggregate the stages of shrub fallow, grass fallow, and cultivated land into the overarching 'shifting cultivation' land use class. We made an exception for the 'tree fallow' stage, which in our classification constitutes the 'secondary forest' class, and for which we were able to obtain more consistent temporal information. However, this class might contain plots that have been fallow for periods ranging from six years to several decades. In many cases, local farmers consider such plots as still being within the shifting cultivation cycle, and may thus clear and cultivate them again at any time. Given that we discuss the potential emergence of a forest transition mostly on the basis of this 'secondary forest' class, our results must be interpreted with particular caution.

The 'old-growth forest' class refers to areas for which farmers knew of no timber extraction activity to have taken place in the last three decades. The assignment of areas to this class was further supported by our ancillary data. The 'degraded forest' class, by contrast, contains areas where some type of timber extraction is visibly going on, ranging from areas where selective logging of some hard woods has barely started to areas where heavy extraction has been going on for several years, and it also includes forest edges accidentally burned in connection with shifting cultivation activities. As in the case of 'secondary forest', this understanding of the difference between the 'old-growth' and 'degraded' forest classes calls for particular caution when interpreting our results.

Clove-related land uses we disaggregate into three classes: 'pasture with clove trees', where clove cultivation coexists with grazing; 'dense clove plantation', where clove is grown in monoculture; and 'young clove plantation', which covers the intermediate land use between preparation and planting of a plot with small clove trees and the beginning of actual production. Agroforest we likewise disaggregate into three classes. The first two, 'closed' and 'open agroforest', we consider in this study to indicate vanilla cultivation, which in this area is often grown together with subsistence fruit tree species or other cash crops like coffee. 'Closed agroforest' usually corresponds to an intermediate step between old-growth or degraded forest and open agroforest. The third agroforest class is 'clovedominated agroforest', which corresponds to an open agroforest containing a large number of clove trees.

The definitions of these land use classes are in line with how agroforestry and clove-related classes are commonly defined based on land management characteristics in this region (Arimalala et al., 2018; Michels et al., 2011), and our study helps to redress the invisibility of agroforestry systems in mapping endeavours in Madagascar (Baker et al., 2013). However, caution is required when interpreting our results concerning these land uses, as there are some overlaps, and especially because the differences between the various agroforest classes are more nuanced in reality than the discrete, fixed categories we employ in this study. 


\section{Supplementary Information references}

Arimalala, N., Penot, E., Michels, T., Rakotoarimanana, V., Michel, I., Ravaomanalina, H., .. . Danthu, P. (2018). Clove based cropping systems on the east coast of Madagascar: how history leaves its mark on the landscape. Agroforestry Systems. doi:10.1007/s10457018-0268-9

BNGRC, \& OCHA. (2017). Madagascar administrative level 0 - 4 boundaries. Retrieved from: $\quad$ https://data.humdata.org/dataset/madagascar-administrative-level-0-4boundaries

Bourgoin, J., Castella, J.-C., Pullar, D., Lestrelin, G., \& Bouahom, B. (2012). Toward a land zoning negotiation support platform: "Tips and tricks" for participatory land use planning in Laos. Landscape and Urban Planning, 104(2), 270-278. doi:https://doi.org/10.1016/j.landurbplan.2011.11.008

Brown, G., \& Fagerholm, N. (2015). Empirical PPGIS/PGIS mapping of ecosystem services: A review and evaluation. Ecosystem Services, 13, 119-133. doi:http://dx.doi.org/10.1016/j.ecoser.2014.10.007

Brown, G., \& Kyttä, M. (2018). Key issues and priorities in participatory mapping: Toward integration or increased specialization? Applied Geography, 95, 1-8. doi:https://doi.org/10.1016/j.apgeog.2018.04.002

ESRI. (2017). ArcGIS ver. 10.5.1. Redlands, CA, USA: ESRI.

Hansen, M. C., Potapov, P. V., Moore, R., Hancher, M., Turubanova, S. A., Tyukavina, A., . . . Townshend, J. R. G. (2013). High-Resolution Global Maps of 21st-Century Forest Cover Change. Science, 342(6160), 850-853. doi:10.1126/science.1244693

Heinimann, A., Flint, C., Bernhard, R., \& Hett, C. (2017). Putting upland agriculture on the map: The TABI experience in Laos. In M. Crains (Ed.), Shifting Cultivation Policies: Balancing Environmental and Social Sustainability. Wallingford, United Kingdom: CABI.

Klain, S. C., \& Chan, K. M. A. (2012). Navigating coastal values: Participatory mapping of ecosystem services for spatial planning. Ecological Economics, 82, 104-113. doi:http://dx.doi.org/10.1016/j.ecolecon.2012.07.008

MEEF, CI, USAID/Madagascar, IRG, ONE, \& FTM. (2007). Change in Natural Forest Cover 1990, 2000, 2005. Antananarivo: Ministère de l'Environnement et des Eaux et Forêts (MEEF), Conservation International (CI), USAID/Madagascar, International Resources Group (IRG), Office National d'Environnement (ONE) et Foibe Taosaritanin'i Madagasikara (FTM).

Mertz, O., Müller, D., Sikor, T., Hett, C., Heinimann, A., Castella, J.-C., . . . Zhanli. (2012). The forgotten D: challenges of addressing forest degradation in complex mosaic landscapes under REDD+. Geografisk Tidsskrift-Danish Journal of Geography, 112(1), 63-76. doi:10.1080/00167223.2012.709678

Michels, T., Bisson, A., Ralaidovy, V., Rabemananjar, H., Jahiel, M., \& Malézieux, E. (2011). Horticultural agroforestry systems in the humid tropics: Analysis of clove tree-based systems in Madagascar. Acta Hortic., 894, 161-167.

Nackoney, J., Rybock, D., Dupain, J., \& Facheux, C. (2013). Coupling participatory mapping and GIS to inform village-level agricultural zoning in the Democratic Republic of the 
Congo. Landscape and Urban Planning, 110, 164-174. doi:http://dx.doi.org/10.1016/j.landurbplan.2012.11.004

ONE, DGF, FTM, MNP, \& CI. (2013). Evolution de la Couverture de forêts naturelles à Madagascar 2005-2010. Antananarivo.

Schmidt, F. (2018). GeoSetter Version 3.5. Retrieved from https://www.geosetter.de/en/mainen/

Styger, E., Rakotondramasy, H. M., Pfeffer, M. J., Fernandes, E. C. M., \& Bates, D. M. (2007). Influence of slash-and-burn farming practices on fallow succession and land degradation in the rainforest region of Madagascar. Agriculture, Ecosystems and Environment, 119, 257-269.

Trimble. (2013). eCognition Developer 8. Munich, Germany: Trimble Germany GmbH.

Zaehringer, J., Eckert, S., \& Messerli, P. (2015). Revealing Regional Deforestation Dynamics in North-Eastern Madagascar-Insights from Multi-Temporal Land Cover Change Analysis. Land, 4(2), 454.

Zaehringer, J. G., Llopis, J. C., Latthachack, P., Thein, T. T., \& Heinimann, A. (2018). A novel participatory and remote sensing-based approach to mapping annual land use change on forest frontiers in Laos, Myanmar, and Madagascar. Journal Of Land Use Science, 1-16. 
Table SI.2. Medium-resolution remote sensing data employed in the study.

\begin{tabular}{|c|c|c|c|c|}
\hline Sensor & Acquisition date & Spatial res. & Year assessed & Study landscape \\
\hline Sentinel 2 & 15 Feb, 2018 & 10 m/pixel & 2017 & Fizono and Beanana \\
\hline Sentinel 2 & 07 Nov, 2017 & 10 m/pixel & 2017 & Fizono and Beanana \\
\hline Sentinel 2 & 10 Feb, 2017 & 10 m/pixel & 2016 & Fizono \\
\hline Sentinel 2 & 20 Feb, 2017 & 10 m/pixel & 2016 & Beanana \\
\hline Sentinel 2 & 03 Oct, 2016 & 10 m/pixel & 2016 & Beanana \\
\hline Sentinel 2 & 12 Nov, 2016 & 10 m/pixel & 2016 & Fizono \\
\hline Sentinel 2 & 01 Nov, 2016 & 10 m/pixel & 2016 & Fizono \\
\hline Sentinel 2 & 18 Dec, 2015 & 10 m/pixel & 2015 & Beanana \\
\hline Landsat 8 OLI & 05 Apr, 2015 & 30 m/pixel & 2014 & Beanana \\
\hline Landsat 8 OLI & 30 Dec, 2014 & 30 m/pixel & 2014 & Fizono and Beanana \\
\hline Landsat 8 OLI & 28 Nov, 2014 & 30 m/pixel & 2014 & Fizono and Beanana \\
\hline Landsat 8 OLI & 11 Dec, 2013 & 30 m/pixel & 2013 & Fizono and Beanana \\
\hline Landsat 8 OLI & 01 May, 2013 & 30 m/pixel & 2012 & Beanana \\
\hline Landsat 7 ETM+ & 02 Feb, 2013 & 30 m/pixel & 2012 & Fizono \\
\hline Landsat 7 ETM+ & 30 Nov, 2012 & 30 m/pixel & 2012 & Beanana and Fizono \\
\hline Landsat 7 ETM+ & 14 Dec, 2011 & 30 m/pixel & 2011 & Beanana and Fizono \\
\hline Landsat 7 ETM+ & 20 May, 2011 & 30 m/pixel & 2010 & Beanana \\
\hline Landsat 7 ETM+ & 09 Sep, 2010 & 30 m/pixel & 2010 & Beanana and Fizono \\
\hline Landsat $5 \mathrm{TM}$ & 09 May, 2010 & 30 m/pixel & 2009 & Fizono \\
\hline Landsat 5 TM & 02 Feb, 2010 & 30 m/pixel & 2009 & Beanana \\
\hline Landsat 5 TM & 30 Nov, 2009 & 30 m/pixel & 2009 & Fizono \\
\hline Landsat 7 ETM+ & 06 Nov, 2009 & 30 m/pixel & 2009 & Beanana \\
\hline Landsat 5 TM & 06 May, 2009 & 30 m/pixel & 2008 & Beanana and Fizono \\
\hline Landsat 7 ETM+ & 05 Dec, 2008 & 30 m/pixel & 2008 & Fizono \\
\hline Landsat $5 \mathrm{TM}$ & 03 May, 2008 & 30 m/pixel & 2007 & Beanana \\
\hline Landsat 7 ETM+ & 09 Apr, 2008 & 30 m/pixel & 2007 & Beanana \\
\hline Landsat 5 TM & 16 Mar, 2008 & 30 m/pixel & 2007 & Beanana \\
\hline Landsat 5 TM & 28 Jan, 2008 & 30 m/pixel & 2007 & Fizono \\
\hline Landsat 7 ETM+ & 03 Dec, 2007 & 30 m/pixel & 2007 & Fizono \\
\hline Landsat 5 TM & 25 Jan, 2007 & $30 \mathrm{~m} /$ pixel & 2006 & Fizono \\
\hline Landsat 7 ETM+ & 02 Feb, 2007 & 30 m/pixel & 2006 & Beanana \\
\hline Landsat 5 TM & 22 Nov, 2006 & 30 m/pixel & 2006 & Beanana and Fizono \\
\hline Landsat 5 TM & $01 \mathrm{Jul}, 2006$ & 30 m/pixel & 2005 & Fizono \\
\hline Landsat 5 TM & 15 Jun, 2006 & 30 m/pixel & 2005 & Fizono \\
\hline Landsat 7 ETM+ & 13 Dec, 2005 & 30 m/pixel & 2005 & Beanana and Fizono \\
\hline Landsat 7 ETM+ & 11 Nov, 2005 & 30 m/pixel & 2005 & Fizono \\
\hline Landsat 5 TM & 08 Mar, 2005 & $30 \mathrm{~m} /$ pixel & 2004 & Fizono \\
\hline Landsat 7 ETM+ & 12 Feb, 2005 & 30 m/pixel & 2004 & Beanana and Fizono \\
\hline Landsat 7 ETM+ & 24 Nov, 2004 & 30 m/pixel & 2004 & Beanana \\
\hline
\end{tabular}




\begin{tabular}{|c|c|c|c|c|}
\hline Landsat 7 ETM+ & 01 Jun, 2004 & 30 m/pixel & 2003 & Fizono \\
\hline Landsat 7 ETM+ & 16 May, 2004 & 30 m/pixel & 2003 & Beanana and Fizono \\
\hline Landsat 7 ETM+ & 22 Nov, 2003 & 30 m/pixel & 2003 & Fizono \\
\hline Landsat 7 ETM+ & 23 Feb, 2003 & 30 m/pixel & 2002 & Beanana and Fizono \\
\hline Landsat 7 ETM+ & 02 Oct, 2002 & 30 m/pixel & 2002 & Fizono \\
\hline Landsat 7 ETM+ & 04 Feb, 2002 & 30 m/pixel & 2001 & Fizono \\
\hline Landsat 7 ETM+ & 15 Oct, 2001 & 30 m/pixel & 2001 & Beanana and Fizono \\
\hline Landsat 5 TM & 08 Jan, 2001 & 30 m/pixel & 2000 & Beanana and Fizono \\
\hline Landsat 5 TM & 23 Dec, 2000 & 30 m/pixel & 2000 & Beanana and Fizono \\
\hline Landsat 5 TM & 11 Apr, 2000 & 30 m/pixel & 1999 & Fizono \\
\hline Landsat 7 ETM+ & 29 Dec, 1999 & 30 m/pixel & 1999 & Beanana \\
\hline Landsat 7 ETM+ & 27 Nov, 1999 & 30 m/pixel & 1999 & Fizono \\
\hline Landsat 5 TM & 20 Feb, 1999 & 30 m/pixel & 1998 & Beanana and Fizono \\
\hline Landsat 5 TM & 18 Dec, 1998 & 30 m/pixel & 1998 & Beanana and Fizono \\
\hline Landsat 5 TM & 01 Feb, 1998 & 30 m/pixel & 1997 & Beanana and Fizono \\
\hline Landsat 5 TM & 29 Nov, 1997 & 30 m/pixel & 1997 & Beanana and Fizono \\
\hline Landsat 5 TM & 26 Sep, 1997 & 30 m/pixel & 1997 & Beanana \\
\hline Landsat 5 TM & 03 Apr, 1997 & 30 m/pixel & 1996 & Fizono \\
\hline Landsat 5 TM & 29 Jan, 1997 & 30 m/pixel & 1996 & Fizono \\
\hline Landsat 5 TM & 28 Dec, 1996 & 30 m/pixel & 1996 & Beanana and Fizono \\
\hline Landsat 5 TM & 28 Feb, 1996 & 30 m/pixel & 1995 & Beanana and Fizono \\
\hline Landsat 5 TM & 10 Dec, 1995 & 30 m/pixel & 1995 & Fizono \\
\hline Landsat 5 TM & 24 Jan, 1995 & 30 m/pixel & 1994 & Beanana and Fizono \\
\hline Landsat 5 TM & 21 Nov, 1994 & 30 m/pixel & 1994 & Beanana and Fizono \\
\hline Landsat 5 TM & 15 May, 1994 & 30 m/pixel & 1993 & Fizono \\
\hline Landsat 5 TM & 29 May, 1994 & 30 m/pixel & 1993 & Beanana \\
\hline Landsat 5 TM & 20 Dec, 1993 & 30 m/pixel & 1993 & Beanana and Fizono \\
\hline Landsat 5 TM & 26 May, 1993 & 30 m/pixel & 1992 & Beanana and Fizono \\
\hline Landsat 5 TM & 17 Dec, 1992 & 30 m/pixel & 1992 & Fizono \\
\hline Landsat 5 TM & 26 Sep, 1991 & 30 m/pixel & 1991 & Fizono \\
\hline Landsat 5 TM & 29 Jan, 1991 & 30 m/pixel & 1990 & Beanana \\
\hline Landsat 5 TM & 12 Dec, 1990 & 30 m/pixel & 1990 & Beanana and Fizono \\
\hline
\end{tabular}




\section{SI.3. Object-based segmentation detail, Beanana landscape.}

Original image: Pléiades 1A sensor, (acquired on 29.03.2016).

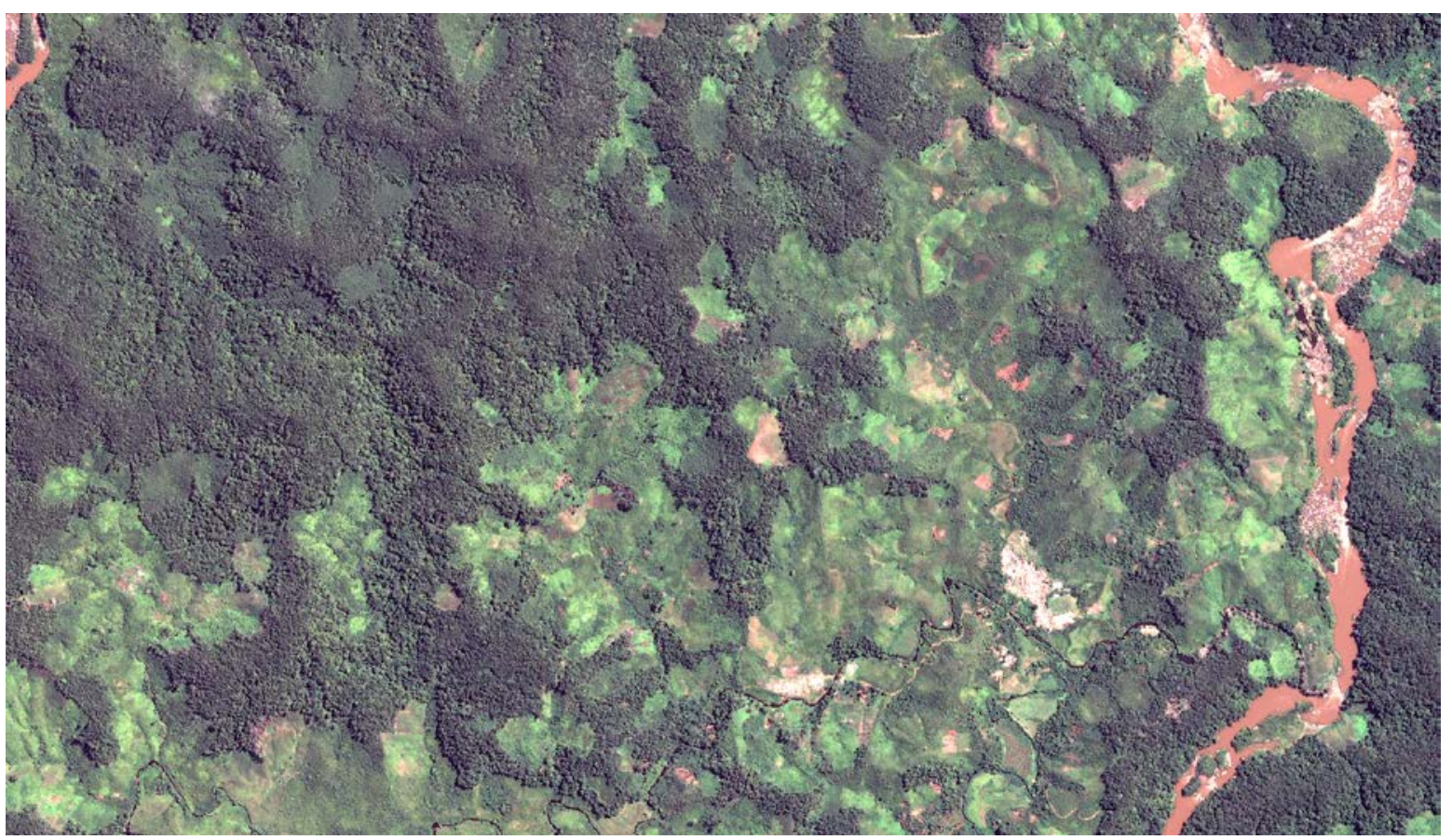

Resulting plot-level segmentation.

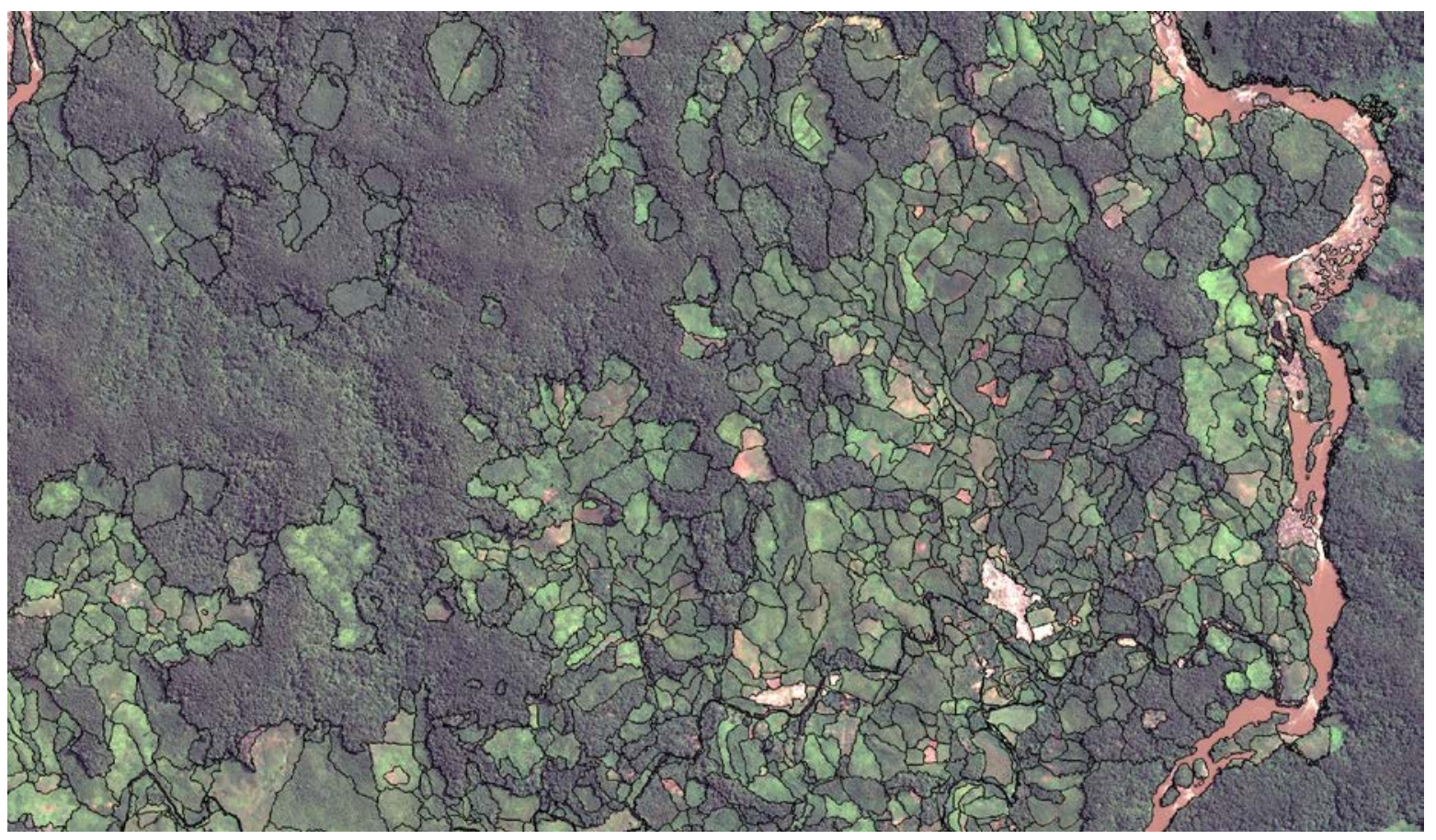

